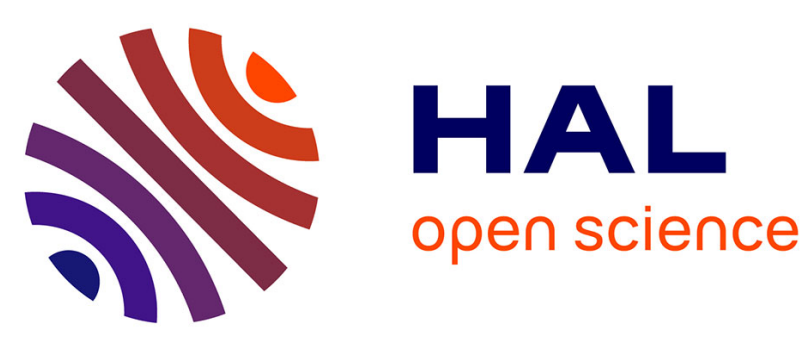

\title{
Selective Profiling of Saponins from Gypsophila trichotoma Wend. by HILIC Separation and HRMS Detection
}

Reneta Gevrenova, Ventzislav Bardarov, Krum Bardarov, Laurence Voutquenne-Nazabadioko, Max Henry

\section{To cite this version:}

Reneta Gevrenova, Ventzislav Bardarov, Krum Bardarov, Laurence Voutquenne-Nazabadioko, Max Henry. Selective Profiling of Saponins from Gypsophila trichotoma Wend. by HILIC Separation and HRMS Detection. Phytochemical Analysis, 2018, 29 (3), pp.250-274. 10.1002/pca.2739 . hal01996248

\section{HAL Id: hal-01996248 \\ https://hal.univ-reims.fr/hal-01996248}

Submitted on 22 Sep 2021

HAL is a multi-disciplinary open access archive for the deposit and dissemination of scientific research documents, whether they are published or not. The documents may come from teaching and research institutions in France or abroad, or from public or private research centers.
L'archive ouverte pluridisciplinaire HAL, est destinée au dépôt et à la diffusion de documents scientifiques de niveau recherche, publiés ou non, émanant des établissements d'enseignement et de recherche français ou étrangers, des laboratoires publics ou privés. 


\section{Selective profiling of saponins from Gypsophila trichotoma Wend. by HILIC separation and HRMS detection}

Reneta Gevrenova ${ }^{1}$, Ventzislav Bardarov ${ }^{2}$, Krum Bardarov ${ }^{3}$, Laurence VoutquenneNazabadioko ${ }^{4}$, Max Henry ${ }^{5}$

${ }^{1}$ Faculty of Pharmacy, Medical University-Sofia, 2 Dunav str., 1000 Sofia, Bulgaria

${ }^{2}$ Hromana Ltd, 78 Samokov str., 1113 Sofia, Bulgaria

${ }^{3}$ Inobiotech, 78 Samokov str., 1113 Sofia, Bulgaria

${ }^{4}$ Institut of Molecular Chemistry of Reims, UMR CNRS 7312, Bâtiment 18, BP 1039, 51687 Reims cedex 2, France

${ }^{5}$ MoBAT team - SRSMC UMR 7565 CNRS-Université de Lorraine, F-54506 Vandoeuvre les Nancy cedex, France

Corresponding author: Reneta Gevrenova

Tel.: +35929236 531; fax: +35929879874

E-mail: rgevrenova@gmail.com 


\begin{abstract}
Introduction: Roots of Gypsophila trichotoma Wend. (Caryophyllaceae) are rich source of Glucuronide Oleanane-type Triterpenoid Carboxylic Acid 3,28-O-Bidesmosides (GOTCAB). These saponins have been reported to possess synergistic cytotoxicity in combination with type I ribosome-inactivating protein saporin.

Objective: To develop ultra high-performance liquid chromatography - electrospray/high resolution mass spectrometry (UHPLC-ESI/HRMS) acquisition strategy for the recognition of Gypsophila GOTCAB saponins.
\end{abstract}

Methodology: A highly-selective hydrophilic interaction UHPLC method (Si-HILIC UHPLC) was developed for the separation of GOTCAB saponins from the methanol-aqueous root extract of G. trichotoma (GTR). UHPLC was coupled to an Orbitrap mass spectrometer equipped with heated electrospray ionization (HESI) probe. ESI-HRMS and tandem MS/MS data of the separated compounds was used for saponins structure assignment.

Results: Based on the conformity of the fragmentation of eleven previously identified $G$. trichotoma saponins, 21 GOTCAB forming between 2 and 4 isobaric and positional isomers are identified with proposals for their structures. Tables with assignment of characteristic fragment ions and more than 10 newly identified saponins in GTR were described. Fragmentation rules for tentative identification of three major types of saponins from GTR were summarized and possible fragmentation pathways were proposed. Type I and II consisted of acylated and sulfated GOTCAB, respectively, while type III included acylated and sulfated saponins. The type II sulfated GOTCAB saponins were all new compounds.

Conclusions: The study demonstrates the potential of the coupling of high-selective ( $\mathrm{Si}$ )HILIC UHPLC with HRMS and MS/MS detection for analysis and identification of triterpenoid saponins.

KEY WORDS: GOTCAB saponins, (Si) HILIC UHPLC, ESI-HRMS, structure interpretation 


\section{INTRODUCTION}

Saponins are secondary metabolites widespread distributed mainly in plant species and chemically referred to triterpenoid and steroidal glycosides (Vincken et al., 2007). Indeed, saponins have potential industrial application as emulsifiers, preservatives, additives to foods and pharmaceutical products (Güçlü-Ustundag et al., 2007; Piorkowski and McClements, 2014). Saponins have been ascribed a number of pharmacological activities, the most important ones being lowering of serum cholesterol levels (Francis et al., 2002), cytostatic and cytotoxic effects on malignant tumor cells (Bachran et al., 2008; Podolak et al., 2010). In addition, saponins combined with conventional chemotherapeutic agents improved inhibitory effect on tumor growth in vitro and in vivo (Fuch et al., 2009). Moreover, saponin-adjuvanted particulate vaccines were reported as immunostimulatory complexes to have great potential as cancer immunotherapeutics (Scene and Sutton, 2006). Among other interesting properties of saponins are their role in permeabilization of the cell membrane (Gilabert-Oriol et al., 2013) and synergisting enhancement of the toxicity of immunotoxines (Bottger et al., 2013; Roger et al., 2016).

Gypsophila species roots are extremely rich source of Glucuronide Oleanane-type Triterpenoid Carboxylic Acid 3,28-O-Bidesmosides (GOTCAB), having a glucuronic acid moiety at C-3 hydroxyl group of the aglycone (Tan et al., 1999; Henry, 2005; Bottger and Melzig, 2010; Zhang et al., 2013). Previous reports have shown that saponins from Gypsophila oldhamiana and $G$. pilulifera display cytotoxic activity against different human cancer cell lines (Bai et al, 2007; Arslan et al, 2012; Zhang et al, 2013). It has also been reported that G. paniculata and G. arrostii var. nebulosa saponins enhance the cytotoxicity of the type I ribosome - inactivating protein (RIP-I) saporin from Saponaria officinalis (Weng et al, 2008; Arslan et al, 2013).

In our previous study eleven new GOTCAB saponins were isolated from the roots of Gypsophila trichotoma Wend. var. trichotoma originated from Bulgaria (VoutquenneNazabadioko et al., 2013). They have a commonly gypsogenin as aglycone substituted at C-3 with a branched trisaccharide chain ending with variable pentose unit (xylose/arabinose) and at C-28 with an ester-bonded oligosaccharide chain possessing methoxycinnamoyl, acetyl and (or) sulfate groups.

Recently, the synergistic cytotoxicity of nine newly isolated GOTCAB saponins from $G$. trichotoma in combination with type I ribosome-inactivating protein (RIP-I) was evaluated in vitro on human breast cancer cell line and quantitative structure-activity relationship (QSAR) was established (Gevrenova et al., 2015).

Based on these findings, Gypsophila saponins are important analytical targets, needing of effective tools for their separation, identification and quantitation.

Some papers describe advantages of normal phase (Cheok et al., 2014), supercritical fluid chromatography (SFC) (Huang et al., 2016) and especially HILIC mode for saponins separation (Guo and Zhang, 2014) and were more selective, in comparison with the popular reverse phase separation, allowing separation and isolation of isomers in a pure form, which is a key step in the investigation of chemical structure and biological properties of individual compounds. In addition, the modern hyphenated techniques combining the better (and faster) separation with mass spectrometric detection offer additional structural information, helping to deduce the chemical structure of separated pure compounds (Zhang et al., 2013; Huang et al., 2016; Xing et al., 2012).

Thus, the present study aims to enlarge the knowledge about the nature of G. trichotoma GOTCAB saponins by improvement of their separation on silica-based HILIC core-shell column (in addition to the popular RP separation) and exploring the capabilities of ESIHRMS and tandem MS/MS data for their structural assignment. 


\section{EXPERIMENTAL}

\section{Plant material and sample preparation}

Gypsophila trichotoma Wend. roots were collected in August 2004 from the Black Sea coast (Kavarna region) $\left(43^{\circ} 25^{\prime} 60^{\prime \prime} \mathrm{N}-28^{\circ} 19^{\prime} 60^{\prime \prime} \mathrm{E}\right)$ in Bulgaria and were identified by Dr. R. Gevrenova (Faculty of Pharmacy, Medical University-Sofia, Bulgaria). Voucher specimen of plant material was deposed in the Herbarium of the Faculty of Pharmacy of Nancy, Universite de Lorraine, France (HP101).

Air-dried powdered roots of the plant $(1 \mathrm{~g})$ were extracted with $50 \mathrm{ml} 10 \%$ methanol $(\times 3)$ by sonication for $5 \mathrm{~min}$ at room temperature. The lyophilized extract constituted the crude extract $417.6 \mathrm{mg}$ (GTR).

\section{Triterpenoid saponin references}

Seven saponins (compounds $\mathbf{A} \div \mathbf{G}$ ) (Figure 1, Table 1), previously isolated from $G$. trichotoma, were used as saponin references in this study. Their structure was assigned by NMR and HR-ESI-MS (Voutquenne-Nazabadioko et al. (2013).

\section{Chemicals and Instruments}

The LC-MS analyses were performed on a Q-Exative HESI-HRMS (Thermo Fisher Scientific, Waltham, MA, USA) equipped with an Accela quaternary UHPLC pump and Accela autosampler. Data were processed using Xcalibur ® (Thermo Scientific Co, USA) instrument control/data handling software.

Acetonitrile (hypergrade for LC-MS and formic acid (HPLC-grade) were purchased from Merck (Darmstadt, Germany), while ammonium formate (for mass spectrometry) was provided by Sigma Aldrich (Germany).

\section{UHPLC separation}

Two separation mechanisms were tested: RP separation on Poroshell C18 150 x $3 \mathrm{~mm}, 2.7$ $\mu \mathrm{m}$ column (Agilent, Santa Clara, CA, USA) and HILIC separation on Kinetex Si HILIC 100 x $3 \mathrm{~mm}, 2.6 \mu \mathrm{m}$ column (Phenomenex, Torrance, CA,USA). The mobile phase for RP separation consisted of solution A: acetonitrile/0.08\% formic acid in water 5:95 (v/v) and solution B: $0.08 \%$ formic acid in acetonitrile/water 95:5 (v/v) with gradient starting at $100 \%$ A for $0.5 \mathrm{~min}$ followed by a linear gradient for $18.5 \mathrm{~min}$ to $100 \% \mathrm{~B}$, isocratic elution for 10 min and the mobile phase was returned to the initial conditions in $1 \mathrm{~min}$ and the column was equilibrated for $5 \mathrm{~min}$ before the next run. The flow rate was $250 \mu \mathrm{L} / \mathrm{min}$

The mobile phase for HILIC separation was composed of solution A: $0.02 \mathrm{M}$ ammonium formate in acetonitrile/water 95:5 (v/v) and solution B: $0.02 \mathrm{M}$ ammonium formate in acetonitrile/water 60:40. The gradient program commenced at 100\% A for 1 min followed by a linear gradient for 6 min to $60 \% \mathrm{~A} / 40 \% \mathrm{~B}$, gradient elution to $10 \% \mathrm{~A} / 90 \% \mathrm{~B}$ in the next 8 min, 2 min cleanup at $100 \% \mathrm{~B}$ and the mobile phase was returned to the initial conditions in 2 min followed by $10 \mathrm{~min}$ reconditioning at $100 \% \mathrm{~A}$. The flow rate was $400 \mu \mathrm{L} / \mathrm{min}$. The solvents were filtered through $0.2 \mu \mathrm{m}$ filterers (Millipore, Watford, Ireland).

\section{ESI-MS and MS/MS detection}

HESI Ionization. Vaporizer temperature $250^{\circ} \mathrm{C}$, spray voltage at $3 \mathrm{kV}$, ion transfer tube temperature at $300^{\circ} \mathrm{C}$, sheath gas pressure $35 \mathrm{psi}$ and auxiliary gas flow 10 (arbitrary units) were adjusted for the interphase;

Mass spectral conditions. Full MS/data dependant $\mathrm{MS}^{2}$ were performed in positive and negative ion monitoring mode with the following settings: 35000 FWHM resolution in Full 
MS from 290 to $2000 \mathrm{~m} / z, 80 \mathrm{msec}$ maximal trap filling time, 17500 FWHM resolution for fragment spectra scans with $4 \mathrm{~m} / z$ quadrupole isolation window of precursor ions and $20 \div 40 \mathrm{eV}$ collision energy.

Positive and negative ion monitoring modes were tested, but in the most of experiments negative mode was used on account of its advantages, described below.

MS/MS spectra were recorded after fragmentation at different hcd (Higher Energy Collisional Dissociation) values and used for saponins structural interpretation.

\section{RESULTS AND DISCUSSION}

\section{Optimum conditions for UHPLC-HRMS analysis}

ESI-HRMS detection. Positive and negative ion monitoring of GOTCAB saponins in the course of their ESI-MS detection were compared on the base of sensitivity (the areas of the chromatographic peaks), and selectivity (purity of the "molecular ion" peak).

Figure 2 indicates the ionisation abundance of the selected saponin in the negative and positive ion modes and the marked difference in the ionization responce between negative (Fig. 2a $a_{2}, a_{3}$ ) and positive (Fig. 2 $b_{2}-b_{5}$ ) ion mode of ESI-HRMS detection could be discerned. The chromatograms demonstrate the higher "selectivity" (deprotonated molecular $[\mathrm{M}-\mathrm{H}]$ " ion formation predominantly) and higher sensitivity (much higher peak area AA) in negative ion mode $\left(2 \mathrm{a}_{1}\right)$, in comparison with the detection of molecular $[\mathrm{M}+\mathrm{H}]^{+}$ion in positive ion mode $\left(2 b_{1}\right)$. There are more intensive $[\mathrm{M}-\mathrm{H}]^{-}$ions in negative mode as compared to positive mode. The capability of the instrument used to monitor positive and negative ions simultaneously allows to make such comparison easier. Taking into account the advantages of the negative ion mode of GOTCAB saponins detection, all next experiments were performed using negative ion monitoring SCAN mode of ESI-HRMS detection and MS/MS fragmentation of the $[\mathrm{M}-\mathrm{H}]^{-}$ions.

Comparison of the retention and selectivity of saponins separation by RP and (Si) HILIC modes. The chromatographic behavior of GOTCAB saponin references A-G in HILIC separation mode was compared with RP mode: the order of elution in HILIC mode correlated with the number of sugar residues attached to the gypsogenin and substitution pattern of C-28 ester chain. For example, the earliest eluting saponin references $\mathbf{C}, \mathbf{A}, \mathbf{B}$ with $[\mathrm{M}-\mathrm{H}]^{-}$at $\mathrm{m} / \mathrm{z}$ 1647.637 in HILIC LC-MS are acetylated in a $\beta$-D-fucopyranose ( $\beta$-D-Fucp) and sulfated in a $\beta$-D-glucopyranose ( $\beta$-D-Glcp) moiety of the C-28 ester chain (Fig.1). Saponins possessing diacetylated C-28 ester chain $(\mathbf{E}, \mathbf{F})$ eluted earlier than monoacetylated one (D). The last saponin $\mathbf{G}$ contains no additional substitution in the C-28 ester chain. In HILIC LC-MS analysis, saponin references having a $\alpha$-L-arabinopyranose ( $\alpha$-L-Arap) (A, E) eluted earlier than corresponding isomers with a $\beta$-D-xylopyranose $(\beta$-D-Xylp) $(\mathbf{B}, \mathbf{F})$. The substitution position of acetyl group in fucose moiety modified chromatographic behavior, favoring lower retention time for $\mathbf{C}$ (acetylated in $\beta$-D-Fucp C-3) in comparison with $\mathbf{A}$ (acetylated in $\beta$-DFucp C-4).

Aiming to obtain the best separation of GOTCAB saponins in G. trichotoma roots extract (GTR), RP and HILIC separation mechanisms were tested (Fig. 3). HILIC mode of UHPLC showed some advantages: more than 67 peaks of saponins were separated in less than 16 min by HILIC mode, while 40 ones were eluted in 18 min by RP UHPLC. Retention times (RT) of GOTCAB identified in GTR are described in Table 2. As shown in Figure 3, HILIC mode allowed to separate more saponins' isomers, with higher efficiency and faster. Acidity of the mobile phase in HILIC separation mode slightly influenced the selectivity and improved it with increasing of $\mathrm{pH}$ value. Therefore, and on account of simplification of mobile phase 
preparation, the acidity was not adjusted after preparation of the mobile phase: the $\mathrm{pH}$ value of the ammonium formate water solution was 6.6.

More selective separation of saponins by HILIC UHPLC permits to obtain mass spectra of the pure representatives and their adequate structural assignment on the base of HRMS and MS/MS data. In the case of saponins quantitation, HILIC mode of separation and ESI with SIM detection mode of $[\mathrm{M}-\mathrm{H}]^{-}$molecular ions of saponins could be much effective, but the aim of this work is the profiling and identification of GOTCAB saponins, not their quantitation.

\section{Investigation of the GOTCAB references fragmentation patterns by UHPLC- ESI/HRMS}

UHPLC-ESI/MS analyses of the available saponin references $\mathbf{A} \div \mathbf{G}$ (Fig. 1) served to confirm their presence in GTR and to observe GOTCAB fragmentation patterns, allowing putting forward our strategy for identification of saponins in GTR. ESI/MS data of previously reported saponins (not available as reference substances) $\mathbf{H}$-K were used as well (Fig. 1). The measured values for the monoisotopic masses of $[\mathrm{M}-\mathrm{H}]^{-}$ions and their calculated values are described in Table 1. Fragment MS/MS mass spectra of the $[\mathrm{M}-\mathrm{H}]^{-}$molecular ion of the saponin references were recorded at different values for hcd (higher-energy collisional dissociation). Figure 4 illustrates the capability to obtain an optimal MS/MS spectrum for saponins structural assignment. According to the illustrated case of saponin reference $\mathbf{A}$, hcd values of $25 \div 30$ could be taken as appropriate fragmentation energy giving information for the molecular $[\mathrm{M}-\mathrm{H}]^{-}$ion and enough intensity of the fragment ions.

Figure 5 shows the fragment MS/MS spectra of the $[\mathrm{M}-\mathrm{H}]^{-}$ions of saponin references $\mathbf{A} \div \mathbf{G}$ recorded at hod value 30 . Abundant $[\mathrm{M}-\mathrm{H}]^{-}$were first used for saponins recognition. The MS/MS spectra of the corresponding $[\mathrm{M}-\mathrm{H}]^{-}$were explored for structural assignment of the detected new and/or isobaric compounds.

In GOTCAB saponins, carbohydrate chains were attached to the aglycone through the hydroxyl group at C-3 and carboxyl group at C-28 positions (Fig. 1). According to the structure properties of the saponins, both glycosidic bond at C-3 and ester bond at C-28 showed facile cleavage in (-) ESI-MS/MS to form deglycosylated ions. Thus, saponin references A-K were deglycosylated to form two fragment ions at $\mathrm{m} / \mathrm{z} 939.458$ [M-H-ester chain] $]^{-}$and 469.331 [aglycone-H] $^{-}$(Fig. 5). The signal at $\mathrm{m} / \mathrm{z} 469.331$ pointed to the loss of two carbohydrate chains and, in the same time, corresponded to the deprotonated ion of the aglycone (gypsogenin) (Voutquenne-Nazabadioko et al., 2013). The fragmentation of [gypsogenin- $\mathrm{H}]^{-}$ion yielded the characteristic product ions at $\mathrm{m} / \mathrm{z} 451.321$ [gypsogenin- $\mathrm{H}-$ $\mathrm{H}_{2} \mathrm{O}^{-}, 439.321$ [gypsogenin- $\mathrm{H}_{-} \mathrm{CH}_{2} \mathrm{O}$ ] and 423.326 [gypsogenin- $\left.\mathrm{H}_{-} \mathrm{HCO}_{2} \mathrm{H}\right]^{-}$. Furthermore, $m / z 405.316$ was obtained by concomitant loss of $\mathrm{H}_{2} \mathrm{O}$ (18 uma) and $\mathrm{HCO}_{2} \mathrm{H}$ (46 uma) (Table 1). Formic acid (46 uma) and $\mathrm{CO}_{2}$ (44 uma) have been reported as two possible elimination pathways of a carboxylic function of triterpenic acids in ESI-MS (Sandjo et al., 2017).

At low hcd value (20) saponin references $\mathbf{A} \div \mathbf{C}$ typically produced severat abundant product ions with high intensity at $\mathrm{m} / \mathrm{z} 707.170$ [ester chain-H] $]^{-}$and 1177.510 [M-H-trisaccharidic chain] $]^{-}$(Fig.5 a,b,c, Table 1). However, the abundance of the ion at $\mathrm{m} / \mathrm{z} .707 .170$ was higher because it is generated by a C-28 ester bond cleavage. At high HCD (35), a loss of the ester chain was observed leading to the ion at $\mathrm{m} / \mathrm{z} 707.170$ (acetylated and sulfated tetrasaccharide) with a relevant relative abundance, representing the base peak in $\mathbf{A} \div \mathbf{C}$.

The type of sugar moieties were determined from MS/MS spectra in which a mass difference of 162.053, 146.058 and 176.124 indicated the presence of hexose (Hex), deoxyhexose (dHex) and hexosuronic acid (HexA), respectively; and mass difference of 132.042 indicated the presence of a pentose (Pen) (arabinose/xylose). Regarding saponin references $\mathbf{A} \div \mathbf{C}$, three 
mass intervals of 79.958 (sulfate group), 162.053 (glucose) and 242.011 (glucose + sulfate group) were observed at low hcd value (Table 1). In MS/MS spectra of saponin references $\mathbf{E}$ and $\mathbf{F}$ the mass differences of 42.011 (acetyl group) $(\mathrm{m} / \mathrm{z}$ 1567.680) and 204.064 (glucose + acetyl group) $(\mathrm{m} / \mathrm{z}$ 1405.627) indicated that the associated compounds possess acetylated glucose moiety (Table 1, Fig. 5 e, f). The position of sugars in the saccharide chain could also be roughly determined owing to the fact that the cleavage of the glycosidic bond usually occurred first at outermost glycosidic bond of the saccharide chain linked at C-28.

The fragmentation pathway of $\mathrm{Y}_{0 \alpha}[\mathrm{M}-\mathrm{H}$-ester chain] involved consecutive losses of hexosyl at $m / z 777.398$ [M-H-ester chain-Hex $]^{-}\left(\mathrm{Y}_{0 \alpha} / \mathrm{Y}_{1 \beta}\right)$ and pentosyl residues at $m / z 807.421[\mathrm{M}-\mathrm{H}-$ ester chain-Pent $]^{-}\left(\mathrm{Y}_{0 \alpha} / \mathrm{Y}_{1 \beta^{\prime}}\right)$ from the trisaccharide at $\mathrm{C}-3$ of gypsogenin indicating a ramification in the sugar chain. This is confirmed by the losses of water together with $\mathrm{CO}_{2}$, resulting in abundant fragment ions at $m / z 759.395$ [M-H-ester chain-Hex- $\left.\mathrm{H}_{2} 0\right]^{-}, 583.363$ [M$\mathrm{H}$-ester chain-Hex-Pent- $\left.\mathrm{H}_{2} \mathrm{O}-\mathrm{CO}_{2}\right]^{-}$, and 565.352 [M-H-ester chain-Hex-Pent- $\left.2 \mathrm{H}_{2} \mathrm{O}-\mathrm{CO}_{2}\right]^{-}$, together with ions at $m / z 745.417$ [M-H-ester chain-Pent- $\left.\mathrm{H}_{2} \mathrm{O}-\mathrm{CO}_{2}\right]^{-}$, and 627.354 [M-H-ester chain-Hex-Pent- $\mathrm{H}_{2} \mathrm{O}^{-}$(Table 1, Fig. X). Moreover, typical ions of the $\mathrm{Y}_{0 \alpha}$ fragmentation at $\mathrm{m} / \mathrm{z}, 537.359$ and 519.346 resulted from both formic acid and $\mathrm{CO}_{2}$ elimination. On the other hand, the relative abundance of the ion at $m / z 759\left(\mathrm{Y}_{0 \alpha} / \mathrm{Z}_{1 \beta}\right)$ could be related with the position of glycosylation (Table 1). Thus, $15 \%$ relative abundance of this ion indicated an interglycosidic linkage $(1 \rightarrow 2)$ of the galactose, while the occurrence of the low abundant ion at $m / z 807$ supported by 745 and 727 contributed to the assignment of the arabinose at C-3 of glucuronic acid. The ions at $\mathrm{m} / \mathrm{z} 551.338$ and 511.344 (references D-K) corresponded to the loss of pentose and hexose units together with intramolecular breakage of the glucuronic acid ${ }^{4,5} \mathrm{~A}_{0 \beta}$ and ${ }^{0,2} \mathrm{~A}_{0 \beta}$, respectively (Fig. X) The latter ion corroborated substitution at C-2 and C-3 of glucuronic acid moiety. Both trisaccharides linked at C-3 of the gypsogenin, with terminal $\beta$-D-Xylp or $\alpha$-L-Arap, are identical in mass and fragmentation pattern and it was not possible to confirm the corresponding isomer. The comparison with authentic references for these saponins in GTR allowed verifying the exact configuration.

The length and type of C-28 carbohydrate chain were discovered from (-) ESI-MS fragmentation pattern as well. Thus, the loss of 708.178 amu could be attributed to the monoacetylated and sulfated $\mathbf{C}-28$ tetrasaccharide (saponin references $\mathbf{A} \div \mathbf{C}$ ). The ester chain at $m / z 707.170$ tended to release consequently hexose, one or two deoxyhexoses and an acetyl group, yielding the most abundant fragment ions at $m / z$ 519.101 [ester chain-H-dHex-Ac] ${ }^{-}$

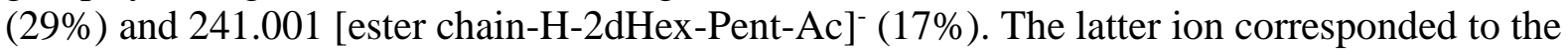
sulfated glucose confirming the position of the sulfate in the C-28 ester chain. Concerning these saponins, it must be taken into account the fact that a sulfated C-28 chain provided series of peaks, the majority of them with low abundance (Table 1, Fig. Y). Some ions characterized the fucose moiety: 607, 591 and 579 resulting from the cross-ring cleavages ${ }^{3,5} \mathrm{~A}_{0 \alpha}(-100),{ }^{0,3} \mathrm{~A}_{0 \alpha}(-116)$ and ${ }^{1,3} \mathrm{~A}_{0 \alpha}(-128)$. An acetyl group esterifies the hydroxyl group at C-4 of the fucose unit as observed by the fragment ions at $\mathrm{m} / \mathrm{z} 503.107$ [707-Pent- $\left.{ }^{3,4} \mathrm{~A}_{0 \alpha}\right]^{-}$and 527.161 [707-Pent- $\left.{ }^{3,5} \mathrm{~A}_{0 \alpha}\right]^{-}$. The xylose moiety was linked at C-4 of the rhamnose unit witnessed by the ion at $m / z 329.022$ [707-Pent-(dHex+Ac) $\left.-^{3,5} \mathrm{~A}_{1 \alpha}\right]^{-}$. Glucose attachment at C3 was confirmed by the ion at $m / z, 301.022$ [707-Pent-(dHex+Ac)- ${ }^{1,3} \mathrm{X}_{1 \alpha}$ ] supported by 371.022 [707-Pent-(dHex+Ac)- $\left.{ }^{3,5} \mathrm{~A}_{1 \alpha}\right]^{-}$. The loss of 628.222 and $670.232 \mathrm{amu}$ corresponded to monoacetylated C-28 tetrasaccharide (reference D) and diacetylated C-28 tetrasaccharide (references $\mathbf{E}$ and $\mathbf{F}$ ), respectively. The loss of 746.263 amu was in agreement with C-28 tetrasaccharide substituted with methoxycinnamoyl moiety (references $\mathbf{J}$ and $\mathbf{K}$ ). This is confirmed by the loss of 178 amu at $m / z$ 1507.659 [M-H-MeCin] due to the loss of methoxycinnamoyl moiety (Table 1). 


\section{Profiling of $G$. trichotoma root extract by UHPLC-ESI/HRMS}

Except for the fully characterized saponin references from G. trichotoma, the tentative identification of the GTR saponins was based on HRMS-measurements, comparison with mass fragmentation observed for the GOTCAB references and literature data (Chen et al., 2011, Voutquenne-Nazabadioko et al., 2013; Zhang et al., 2013). Since GOTCAB have different ester-bonded oligosaccharides and showed different fragment ions, they were classified into 3 types: I - GOTCAB saponins with C-28 oligosaccharide substituted with acyl group; II - GOTCAB saponins with C-28 oligosaccharide substituted with sulfate group; III GOTCAB saponins with C-28 oligosaccharide substituted with both acyl and sulfate groups.

Type I - GOTCAB saponins with C-28 oligosaccharide substituted with acyl group (acylated oligosaccharide). Compounds 1a-d, separated in HILIC UHPLC-MS, shared the same molecular weights as saponin D (Table 2). 1a displayed fragment ions at $\mathrm{m} / \mathrm{z} 1097.730$

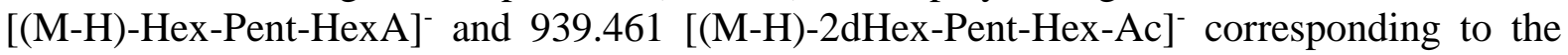
loss of a trisaccharide and ester chain, respectively. Fragment ions at $m / z$ 759.397, 627.354, 583.364 and 565.353 were also consistent with the C-3 trisaccharide of saponin references D (Table 1). At low value of hed 1a produced fragment ions at $m / z 1525.679$ [(M-H)-Ac]', $1405.629[(\mathrm{M}-\mathrm{H})-\mathrm{Hex}]^{-}$and $1141.776[(\mathrm{M}-\mathrm{H})-\mathrm{Hex}-2 \mathrm{Pen}]^{-}$. At high value of hed, this compound displayed fragment ions at $\mathrm{m} / z$ 1363.079 [M-H-Hex-Ac] ${ }^{-}, 807.419$ [M-H-ester

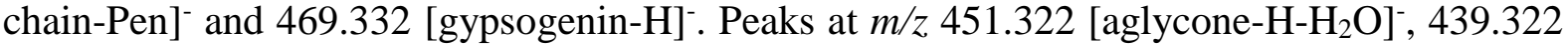
[aglycone- $\left.\mathrm{H}-\mathrm{H}_{2} \mathrm{CO}\right]^{-}, 423.327$ [aglycone- $\left.\mathrm{H}-\mathrm{HCO}_{2} \mathrm{H}\right]^{-}$and 405.316 [aglycone- $\mathrm{H}-\mathrm{HCO}_{2} \mathrm{H}-$ $\mathrm{H}_{2} \mathrm{O}^{-}$are ascribed to the gypsogenin. The loss of $628.212 \mathrm{amu}$ corresponded to a branched tetrasaccharide ending with both hexose and pentose. The isotopic peak profile of $\mathrm{m} / \mathrm{z}$ 1567.673 corroborated the predicted molecular formula of $\mathrm{C}_{72} \mathrm{H}_{111} \mathrm{O}_{37}$, as the relative intensities of isotopic peaks matched closely with the simulated theoretical ones. The retention time of compound $\mathbf{1 a}$ is in good agreement with reference compound $\mathbf{D}$ as well. Thus compound 1a is identified as saponins $\mathbf{D}$ or $3-O-(\alpha-\mathrm{L}$-arabinopyranosyl- $(1 \rightarrow 3)-\beta-\mathrm{D}-$ galactopyranosyl- $(1 \rightarrow 2)]-\beta$-D-glucuronopyranosyl)-28- $O$-( $\beta$-D-glucopyranosyl- $(1 \rightarrow 3)-[\beta$-Dxylopyranosyl- $(1 \rightarrow 4)]$ - $\alpha$-L-rhamnopyranosyl- $(1 \rightarrow 2)-4-O$-acetyl- $\beta$-D-fucopyranosyl)-

gypsogenin. Compound 1c also displayed the same mass fingerprint as compound D suggesting 1c may possess $\beta$-D-Xylp at C-3 trisaccharide, thus favoring longer retention time. Based on the identical molecular weights and MS/MS fragmentation patterns, compounds 1c was tentatively assigned to the isomer of saponin $\mathbf{D}$ or $3-O-(\beta-\mathrm{D}-$ xylopyranosyl- $(1 \rightarrow 3)-\beta$-D-galactopyranosyl- $(1 \rightarrow 2)]-\beta$-D-glucuronopyranosyl)-28- $O$ - $(\beta$-Dglucopyranosyl- $(1 \rightarrow 3)$-[ $\beta$-D-xylopyranosyl- $(1 \rightarrow 4)]-\alpha$-L-rhamnopyranosyl- $(1 \rightarrow 2)-4$ - $O$-acetyl$\beta$-D-fucopyranosyl)-gypsogenin, previously isolated from GTR (Voutquenne-Nazabadioko et al., 2013). Compounds $\mathbf{1 b}$ and $\mathbf{1 d}$ could be differentiated by the location of the acetyl group as observed in saponin reference $\mathbf{C}$. They are tentatively identified in our analysis as the acetate isomers of $\mathbf{1 a}$ and $\mathbf{1 c}$ with fucose position 3 acetylated.

At low value of hed the parent ion at $\mathrm{m} / z 1609.695$ for compounds $\mathbf{2 a - 2 b}$ yielded fragment ions at $\mathrm{m} / z$ 1567.681 [M-H-Ac]', 1477.649 [M-H-Pen] $]^{-}$and 1405.637 [M-H-Hex-Ac]', indicating an ester chain substituted by both terminal acetylated hexose and terminal pentose. By comparing the retention times and MS/MS spectra with those of saponin references, compounds $\mathbf{2 a}$ and $\mathbf{2 b}$ were ascribed to saponins $\mathbf{E}$ and its isomer $\mathbf{F}$, respectively. Thus compound $\mathbf{2 a}$ is $3-O$ - $(\alpha$-L-arabinopyranosyl- $(1 \rightarrow 3)-\beta$-D-galactopyranosyl- $(1 \rightarrow 2)]-\beta$-Dglucuronopyranosyl)-28- $O$ - $(6-O$-acetyl- $\beta$-D-glucopyranosyl- $(1 \rightarrow 3)$-[ $\alpha$-L-arabinopyranosyl$(1 \rightarrow 3)-\beta$-D-xylopyranosyl- $(1 \rightarrow 4)]$ - $\alpha$-L-rhamnopyranosyl- $(1 \rightarrow 2)-4-O$-acetyl- $\beta$-D-

fucopyranosyl)-gypsogenin, and compound $\mathbf{2 b}$ is $3-O-(\beta$-D-xylopyranosyl- $(1 \rightarrow 3)-\beta$-Dgalactopyranosyl-( $(\rightarrow 2)]-\beta$-D-glucuronopyranosyl)-28- $O$ - $(6-O$-acetyl- $\beta$-D-glucopyranosyl- 
$(1 \rightarrow 3)$-[ $\alpha$-L-arabinopyranosyl- $(1 \rightarrow 3)-\beta$-D-xylopyranosyl-( $1 \rightarrow 4)]$ - $\alpha$-L-rhamnopyranosyl$(1 \rightarrow 2)-4-O$-acetyl- $\beta$-D-fucopyranosyl)-gypsogenin

As previously described, two GOTCAB isomers $\mathbf{J}$ and $\mathbf{K}$ with molecular weight 1686 have a methoxycinnamoyl (MeCin) moiety attached to $\beta$-D-Fucp C-4 of the C-28 ester chain (Voutquenne-Nazabadioko et al., 2013). The fragmentation of 3a gave ions at $\mathrm{m} / \mathrm{z} 939.464$ [(M-H)-2dHex-Pent-Hex-MeCin] $]^{-}$and 469.332 [gypsogenin-H] $^{-}$(Table 2). Saponins 3a-3d were identical in mass and fragmentation pattern and it was not possible to confirm which isomer corresponds to previously isolated saponin references $\mathbf{J} / \mathbf{K}$ (not available in this study) by their retention time. However, saponins 3a-3d probably corresponds to the saponin references $\mathbf{J} / \mathbf{K}$ (Voutquenne-Nazabadioko et al., 2013), and their isomers with xylopyranose moiety identified as compouds $4 / 5$ in the roots of Gypsophila perfoliata L. (Chen et al., 2011).

In the (-) ESI-MS spectrum of $\mathbf{4 a}$, the $[\mathrm{M}-\mathrm{H}]^{-}$signal was observed at $\mathrm{m} / z .1727 .734$ indicating molecular weight of 1728 amu, 42.011 mass units higher than that of 3a-3d. This suggested the presence of one additional acetyl group confirmed by the fragment ion at $\mathrm{m} / \mathrm{z} 1667.722$ $[\mathrm{M}-\mathrm{H}-\mathrm{AcOH}]^{-}$. Furthermore, at high hcd (35), the fragment ions at $\mathrm{m} / \mathrm{z} 939.468[(\mathrm{M}-\mathrm{H})-$ 2dHex-Pent-Hex-MeCin-Ac] $]^{-}$and 787.272 [ester chain-H] ${ }^{-}$(4a) showed the presence of MeCin group which was corroborated by the peak at $m / z$ 177.054 [MeCin-H] $]^{-}$(Table 2). The fragmentation pathway involved a loss of $\mathrm{CH}_{3} \mathrm{OH}$ from the cleavage of the $p$-methoxy group, followed by structural rearrangement, resulting in less intensive fragment ion at $\mathrm{m} / \mathrm{z} 145.028$ $\left[\mathrm{MeCin}-\mathrm{H}-\mathrm{CH}_{3} \mathrm{OH}\right]^{-}$. Thus, compounds $\mathbf{4 a - 4 d}$ were probably the acetylated derivatives of compounds 3a-3d.

At low value of hed 5a $\left([\mathrm{M}-\mathrm{H}]^{-}\right.$at $\left.\mathrm{m} / \mathrm{z}, 1741.732\right)$ produced fragment ion at $\mathrm{m} / z$ 1699.725 [M$\mathrm{H}-\mathrm{Ac}]^{-}$and 1187.580 [M-H-Pent-Hex-HexA-2Ac] ${ }^{-}$(Table 2). MS/MS data corroborated ester chain consisting of diacetylated C-28 tetrasaccharide. Thus, we tentatively assigned compounds 5a-5d to four isomers including previously isolated saponins $\mathbf{H}$ and $\mathbf{I}$ (Voutquenne-Nazabadioko et al., 2013). It was not possible to confirm which isomer corresponds to references $\mathbf{H} / \mathbf{I}$ (not available in this study) by their retention time. However, similarly to the results obtained for saponins references $\mathbf{A}-\mathbf{C}$, compounds $\mathbf{5 c}$ and $\mathbf{5 d}$ were attributed to compounds $\mathbf{H}$ and $\mathbf{I}$, respectively.

At low value of hed, the parent ion at $\mathrm{m} / z 1725.738[\mathrm{M}-\mathrm{H}]^{-}$(6a) gave three significant fragments at $m / z 1683.748$ [M-H-Ac] ${ }^{-}, 1593.704$ [M-H-Pen] $]^{-}$and 1171.584 [M-H- Pent-HexHexA-2Ac] $]^{-}$This fragmentation pattern matched with those of compound 3 reported in Gypsophila perfoliata or 3-O- $\beta$-D-galactopyranosyl- $(1 \rightarrow 2)-[\beta$-D-xylopyranosyl- $(1 \rightarrow 3)]-\beta$-Dglucuronopyranosyl gypsogenin $\alpha$-L-arabinopyranosyl- $(1 \rightarrow 3)-\beta$-D-xylopyranosyl- $(1 \rightarrow 4)-\alpha-\mathrm{L}-$ rhamnopyranosyl-( $1 \rightarrow 2)$-[3,4-di- $O$-acetyl- $\beta$-D-quinovopyranosyl- $(1 \rightarrow 4)]-\beta$-D-

fucopyranoside (Chen et al., 2011). The MS/MS data of $\mathbf{6 a}$ were similar to those of 5a, except for the appearance of an additional deoxyhexose unit, instead of hexose moiety in $\mathbf{H} / \mathbf{I}$ (Table 2). This compound is totally different in their structure of the C-28 ester chain possessing a quinovose moiety.

The MS/MS spectra of 7a $\left([\mathrm{M}-\mathrm{H}]^{-}\right.$at $\mathrm{m} / \mathrm{z}$ 1729.733) gave the fragment ion at $\mathrm{m} / \mathrm{z} 939.461$ [(M-H)-2dHex-2Hex-Pen-Ac]', suggesting the presence of one additional hexose unit in the C-28 ester chain in comparison with saponin reference D. These data suggested that this saponin is new and was note previously described in the literature, independently the location of the hexose unit.

The $[\mathrm{M}-\mathrm{H}]^{-}$signal at $\mathrm{m} / \mathrm{z} 1435.641$ in compounds $\mathbf{8 a - 8 d}$ associated to the fragment ions at $\mathrm{m} / \mathrm{z}$ 939.450 [M-H-2dHex-Hex-Ac] ${ }^{-}$and 469.332 [gypsogenin-H] $^{-}(\mathbf{8 a})$, indicated the absence of a pentose moiety in the ester chain in comparison with saponin D (Table 2). The loss of a pentose moiety in the ester chain whatever the type of pentose unit in the C-3 chain and the 
location of the acetyl group indicated that this saponin is new and was note previously described in the literature.

Type II - GOTCAB saponins with C-28 oligosaccharide substituted with sulfate group. This group was characterized by the occurrence of a base peak corresponding to the C-28 ester chain (Table 2). Moreover, typical ions of deoxyhexose moiety internal cleavage were observed: ${ }^{3,5} \mathrm{X}_{0 \alpha}\left([\right.$ ester chain-H-58] $),{ }^{0,3} \mathrm{X}_{0 \alpha}\left([\text { ester chain-H-74] }]^{-}\right){ }^{1,3} \mathrm{X}_{0 \alpha}([$ ester chain-H-86] $)$, $\mathrm{Y}_{2 \alpha^{\prime}}{ }^{3,4} \mathrm{X}_{0 \alpha}([$ ester chain-H-Pent-30]') (9-15) (Fig.Y). In addition, the fragmentation pattern afforded an abundant ion at $m / z 519$ [ester chain-H-dHex] (fragment $\mathrm{C}_{1 \alpha}$ ) or [ester chain-H$\mathrm{dHex}-\mathrm{Pent} / \mathrm{dHex} / \mathrm{Hex}]$ indicating terminal position of the additional sugar moieties (9-12). The fragment at $m / z 329$ allowed situating the pentose at C-4 of the second deoxyhexose, while a C-3 linked hexose was evidenced by the ion at $m / z$ 371. This behavior was similar to the fragmentation described for the saponin references A-C (Table1). The sulfate group was linked at hexose unit witnessed by the ion at $m / z 241\left({ }^{3} \mathrm{X}_{2 \alpha}\right)$ (Fig. Y). Thus, the ester chain in 9-12 could be assigned as $O$-sulfate-hexosyl-( $1 \rightarrow 3)$-[pentosyl-( $1 \rightarrow 4)]$-deoxyhexosyl-( $1 \rightarrow 2)$ deoxyhexoside.

The base peak at $m / z 665.160$ in MS/MS spectra of compounds 9a and 9b $\left([\mathrm{M}-\mathrm{H}]^{-}\right.$at $\mathrm{m} / \mathrm{z}$ 1605.626) corresponded to the aforementioned ester chain, thus indicating the loss of the acetate in comparison with the saponin references $\mathbf{A}$ and $\mathbf{B}$ (Table 2, Fig. 3). At low value of hcd, the fragment at $\mathrm{m} / \mathrm{z} 1525.680$ derived from the sulfate group elimination. Our tentative assignment of these sapenins is GOTCAB, having a tetrasacharide chain at $\mathrm{C}-28$ consisting of two desoxyhexoses, pentose, hexose and a sulfate group. These GOTCAB were the most abundant saponins in GTR. To the authors' knowledge there are no literature data for a saponin with matching mass spectral data.

Concerning 10a and 10b, there was mass difference of 14 between their C-3 trisaccharidic chains and that in saponin D, C-3 oligosaccharide was identified as Hex-Hex-Pent. These two compounds have a trisaccharide chain possessing hexose at the place of glucuronic acid. Peaks 11a and 12a showed prominent fragment ions at $\mathrm{m} / \mathrm{z} 665.161$ [ester chain- $\mathrm{H}$ ] suggesting the same ester chain as in saponin 9a (Table 2). The mass difference of 132.042 indicated the loss of a pentose unit and that 11a and 11b possess a C-3 disaccharide chain consisting of hexose and hexosuronic acid. MS data of compounds 12a-12d, showed the [M$\mathrm{H}]^{-}$at $\mathrm{m} / z 1635.638$ corresponding to $162 \mathrm{uma}$ higher than that of 11a, and indicating the presence of an additional hexose unit in C-3 carbohydrate chain. In comparison with compounds 9a-9b, the pentose was replaced by a hexose in the C-3 trisaccharide chain. Saponins 10-12 were not described in the literature.

The fragmentation observed for 13a $\left([\mathrm{M}-\mathrm{H}]^{-}\right.$at $\mathrm{m} / \mathrm{z}$ 1751.684) exhibited the loss of a sulfate group at $\mathrm{m} / z, 1671.691$ and a trisaccharidic chain at $\mathrm{m} / \mathrm{z} 1281.530$. At high value of hcd, the compound generated base fragment ion at $\mathrm{m} / \mathrm{z} 811.198$ [ester chain-H]', suggesting an additional deoxyhexose moiety in C-28 ester chain in comparison with 9a (Table 2). In the same way, peaks 14a $\left([\mathrm{M}-\mathrm{H}]^{-}\right.$at $\left.m / z, 1737.668\right)$ produced a major ion at $m / z, 797.202$ [ester chain-H]'. Fragment ions were in good agreement with those of 9a, except for the appearance of an additional pentose unit in the ester chain (Table 2). Parent ion at $\mathrm{m} / \mathrm{z} 1767.686[\mathrm{M}-\mathrm{H}]^{-}$ (15a) afforded significant fragments at $\mathrm{m} / \mathrm{z} 827.215$ [ester chain- $\mathrm{H}]^{-}, 665.162$ [ester chain-H$\mathrm{Hex}]^{-}$and 503.108 [ester chain- $\left.\mathrm{H}-2 \mathrm{Hex}\right]^{-}$indicating the presence of supplementary hexose unit in the ester chain in comparison with 9a. Compounds 13-15 were newly identified and the location and the type of supplementary sugar unit must be determined.

Type III - GOTCAB saponins with C-28 oligosaccharide substituted with both acyl and sulfate grou. Four compounds 16a-16d with $\left[\mathrm{M}-\mathrm{H}^{-}\right.$at $\mathrm{m} / \mathrm{z} 1647.637$ were observed with 
different retention times in HILIC UHPLC-MS (Table 2). At high value of hcd 16a afforded a fragment ions at $\mathrm{m} / z, 1177.510$ [M-H-Hex-Pen-HexA)] ${ }^{-}$and 939.464 [M-H-2dHex-PentHex-Ac- $\left.\mathrm{SO}_{3}\right]^{-}$corresponding to the loss of C-3 trisaccharide chain and C-28 ester chain, respectively. In addition, 16a displayed fragment ions at $\mathrm{m} / \mathrm{z}, 707.171$ [ester chain-H] $^{-}$(base peak) and 469.332 [gypsogenin-H] ${ }^{-}$. Thus, fragmentation pattern is in agreement with the structure of compound $\mathbf{C}$ previously reported from $G$. trichotoma roots (VoutquenneNazabadioko et al., 2013). Based on the identical molecular weights, retention times and proposed fragmentation patterns observed in the UHPLC-MS analysis, compounds 16d, 16a and 16c were assigned to saponin references $\mathbf{A}, \mathbf{B}$ and $\mathbf{C}$, respectively, named 3-O- $(\alpha-\mathrm{L}-$ arabinopyranosyl-( $1 \rightarrow 3)-\beta$-D-galactopyranosyl-( $1 \rightarrow 2)]-\beta$-D-glucuronopyranosyl)-28-O-(3-Osulfate- $\beta$-D-glucopyranosyl-( $1 \rightarrow 3)$-[ $\beta$-D-xylopyranosyl- $(1 \rightarrow 4)]$ - $\alpha$-L-rhamnopyranosyl-

$(1 \rightarrow 2)-4-O$-acetyl- $\beta$-D-fucopyranosyl)-gypsogenin, $\quad 3-O-(\beta$-D-xylopyranosyl- $(1 \rightarrow 3)-\beta$-Dgalactopyranosyl- $(1 \rightarrow 2)]$ - $\beta$-D-glucuronopyranosyl $)-28-O$ - $(3-O$-sulfate- $\beta$-D-glucopyranosyl$(1 \rightarrow 3)$-[ $\beta$-D-xylopyranosyl- $(1 \rightarrow 4)]$ - $\alpha$-L-rhamnopyranosyl- $(1 \rightarrow 2)-4-O$-acetyl- $\beta$-Dfucopyranosyl)-gypsogenin, and 3-O-( $\alpha$-L-arabinopyranosyl- $(1 \rightarrow 3)-\beta$-D-galactopyranosyl$(1 \rightarrow 2)]$ - $\beta$-D-glucuronopyranosyl)-28- $O$ - $(3-O$-sulfate- $\beta$-D-glucopyranosyl- $(1 \rightarrow 3)$-[ $\beta$-D-

xylopyranosyl- $(1 \rightarrow 4)]$ - $\alpha$-L-rhamnopyranosyl- $(1 \rightarrow 2)-3-O$-acetyl- $\beta$-D-fucopyranosyl)-

gypsogenin, respectively. In addition, $\mathbf{1 6 b}$ and $\mathbf{1 6} \mathbf{c}$ eluted earlier than corresponding pair of isomers 16d and 16a suggesting 16b may possess acetyl group at $\beta$-D-Fucp C-3. Two pairs of isomers differ in the acetyl group position. Compound 16b is thus a new saponin, tentatively named 3-O-( $\beta$-D-xylopyranosyl- $(1 \rightarrow 3)-\beta$-D-galactopyranosyl- $(1 \rightarrow 2)]-\beta$-Dglucuronopyranosyl)-28- $O$ - $(3-O$-sulfate- $\beta$-D-glucopyranosyl- $(1 \rightarrow 3)-[\beta$-D-xylopyranosyl$(1 \rightarrow 4)]$ - $\alpha$-L-rhamnopyranosyl- $(1 \rightarrow 2)-3-O$-acetyl- $\beta$-D-fucopyranosyl)-gypsogenin.

At high value of hcd 17a (parent ion at $m / z 1765.673[\mathrm{M}-\mathrm{H}]^{-}$) produced a base peak at $\mathrm{m} / \mathrm{z}$ 825.215 [ester chain-H] $^{-}$and fragment ions at $\mathrm{m} / \mathrm{z} 1295.554$ [M-H-470] $^{-}, 647.152$ [ester chain-H-MeCin- $\left.\mathrm{H}_{2} \mathrm{O}\right]^{-}$, and 519.104 [ester chain-H-dHex-MeCin] ${ }^{-}$. The formation of fragment ions at $\mathrm{m} / \mathrm{z} \quad 177.054$ and 145.028 was favored for the presence of a methoxycinnamoyl moiety attached to $\mathrm{C}-4$ of the terminal deoxyhexose moiety (instead of an acetyl group in saponin references A-C) witnessed by the fragments at $\mathrm{m} / \mathrm{z} 607$ and 527 (Table 2). Thus, compounds $\mathbf{1 7 a - 1 7 d}$ corresponded probably to the sulfated derivatives of compounds $\mathbf{J} / \mathbf{K}$ with sulfate on the glucose moiety, as deduced from the pic at $\mathrm{m} / \mathrm{z} 241.002$ [ester chain-H-2dHex-Pent-MeCin] $]^{-}$, and were new compounds. Compounds 18a displayed prominent ion at $\mathrm{m} / \mathrm{z}, 749.183$ [ester chain- $\mathrm{H}]^{-}$indicating the presence of additional acetyl group in the ester chain in comparison with saponin references A-C. Thus, compounds 18a$\mathbf{1 8 d}$ corresponded probably to the sulfated derivatives of compound references $\mathbf{E}$ and $\mathbf{F}$ with sulfate on the glucose moiety, as deduced from the pic at $\mathrm{m} / z 241\left[\mathrm{GlcSO}_{3}-\mathrm{H}\right]^{-}$, and were new compounds.

The presence of supplementary pentose in C-28 ester chain was evidenced in saponins 19a19c, which showed related fragmentation pattern as saponins A-C after the loss of this pentose. Similarly, compound 20a with parent ion at $\mathrm{m} / z 1809.693[\mathrm{M}-\mathrm{H}]^{-}, 162.059$ mass units higher than that of saponin references A-C, showed prominent ions at $\mathrm{m} / z$ 1177.503 [MH-trisaccharidic chain-Hex] ${ }^{-}$, with fragments ions at $\mathrm{m} / z$ 869.228 [ester chain-H] $]^{-}$and 707.171 [ester chain-H-Hex] $]^{-}$consistent with one additional hexose unit on the ester chain (Table 2). These compounds (19a-19d and 20a-20d) were not previously described.

MS spectra of the pair of isomers 21a and 21b at $\mathrm{m} / \mathrm{z}, 1525.672$ indicated the absence of both acyl and sulfate groups. The fragmentation pattern consists with that of saponin reference $\mathbf{G}$ (Voutquenne-Nazabadioko et al., 2013; Zhang et al., 2013). Compounds 21a was assigned to saponin reference $\mathbf{G}$, also named 3-O-( $\alpha$-L-arabinopyranosyl- $(1 \rightarrow 3)-\beta$-D-galactopyranosyl$(1 \rightarrow 2)]-\beta$-D-glucuronopyranosyl)-28- $O$ - $(\beta$-D-glucopyranosyl- $(1 \rightarrow 3)$-[ $\beta$-D-xylopyranosyl- 
Nazabadioko et al., 2013). This MS data could also correspond to their isomer 3-O-( $\beta$-Dxylopyranosyl- $(1 \rightarrow 3)-\beta$-D-galactopyranosyl- $(1 \rightarrow 2)]-\beta$-D-glucuronopyranosyl)-28- $O$ - $(\beta$-Dglucopyranosyl- $(1 \rightarrow 3)-[\beta$-D-xylopyranosyl- $(1 \rightarrow 4)]-\alpha-L-r h a m n o p y r a n o s y l-(1 \rightarrow 2)-\beta-D-$ fucopyranosyl)-gypsogenin, isolated previously from the roots of $G$. paniculata (Frechet et al., 1991) and G. oldhamiana (Zhang et al., 2013).

By comparing the retention time and MS/MS of the GTR saponins with those of reference saponins, peaks 1a, 2a, 2b, 16c, 16d, 16a, 21a were ascribed unambiguously to saponin references $\mathbf{D}, \mathbf{E}, \mathbf{F}, \mathbf{C}, \mathbf{A}, \mathbf{B}$ and $\mathbf{G}$, respectively. Other peaks were tentatively identified by detailed studies of their MS and MS/MS data, and by comparison with literature data.

Fragmentation patterns of $G$. trichotoma GOTCAB saponins indicated that they shared the same aglycone, gypsogenin. Saponins appeared to be 3,28-O-bidesmosides containing two carbohydrate chains: one attached via a glycosidic binding at C-3 and one ester-bonded at C28 of aglycone. At hcd=25-30 a majority of GOTCAB typically produced intense ions indicating the loss of both carbohydrate chains without diminishing the ability to distinguish the $[\mathrm{M}-\mathrm{H}]^{-}$ions. At low value of hcd, saponins produced fragment ions attributed to the loss of acyl and (or) sulfate groups, as well as ions indicating the sequential loss of sugar residues. (Figure 5, X,Y, Table 1). Our strategy for recognition of GOTCAB was based on the diagnostic ions for each type saponins in GTR. Thus, the fragment ions attributed to the loss of one acyl group, terminal acylated hexose, and trisaccharidic chain together with one (two) acyl groups, could be considered diagnostic ions for acylated GOTCAB saponins. The relative abundance of ions at $807.416,759.395,745.416$ and 727.405 were related to the position of the glycosylation on the glucuronic acid of the C-3 trisaccharidic chain, more abundant in $\mathrm{C}-2$ than in $\mathrm{C}-3$. The fragmentation of the aglycone gypsogenin yielded the characteristic product ion at $\mathrm{m} / \mathrm{z} 423.3258$ deriving from the loss of $\mathrm{HCO}_{2} \mathrm{H}$. The fragment ions at $\mathrm{m} / \mathrm{z} 665.159,519.101$ and 241.001 together with [ester chain-H] ${ }^{-}$(base peak), and [M$\left.\mathrm{HSO}_{3}\right]^{-}$(at low value of hcd) can be considered as the diagnostic ions for sulfated GOTCAB saponins. In this group, the relevant ions ${ }^{3,5} \mathrm{~A}_{0 \alpha}(-100),{ }^{0,3} \mathrm{~A}_{0 \alpha}(-116)$ and ${ }^{1,3} \mathrm{~A}_{0 \alpha}(-128)$ from the cross-ring cleavages were indicative of deoxyhexose moieties (Fig.Y). The presence of low abundant ions [ester chain-Pent- $\left.(\mathrm{dHex}+\mathrm{Ac}){ }^{3,5} \mathrm{~A}_{1 \alpha}\right]^{-}$and $\left[\text {ester chain-Pent- }(\mathrm{dHex}+\mathrm{Ac}){ }^{-}{ }^{1,3} \mathrm{X}_{1 \alpha}\right]^{-}$ pointed to the hexose and pentose glycosylation position in C-28 ester chain, respectively. Particularly, internal cleavages ${ }^{3,4} \mathrm{~A} 0 \alpha$ and ${ }^{3,5} \mathrm{~A}_{0 \alpha}$ indicated acylation at $\mathrm{C}-4$ terminal deoxyhexose hydroxyl. Acylated and sulfated GOTCAB showed the same fragmentation pattern as the saponin references with sulfated C-28 oligosaccharide together with the ion at $\mathrm{m} / \mathrm{z} 241.001\left[\mathrm{GlcSO}_{3}-\mathrm{H}\right]^{-}$. Both $\mathrm{C}-3$ trisaccharides with terminal xylose/arabinose cause the appearance of characteristic pairs of saponins differing in the terminal sugar of $\mathrm{C}-3$ trisaccharidic chain. Additional pairs of isomers resulted from the substitution with acetyl, sulfate and methoxycinnamoyl groups at C-28 ester chain. It seems that most of $G$. trichotoma saponins occur as isomeric pairs in the profiling with members of pairs differing in retention times based on their matching mass fingerprints. Their structural differences were attributed to both the pentose unit in C-3 trisaccharide and the location of acyl groups. The existence of isomers possessing acetyl group on the fucose moiety could be attributed to an isomerization by migration of the acetate from the position 3 to the position 4 and reversely.

The main finding of this study was that we put forward a strategy for the tentative identification of Gypsophila GOTCAB saponins by HRMS and MS/MS data. This strategy was based on the fact that GOTCAB have two oligosaccharidic chains and the aglycone part is triterpenoid carboxylic acid. In this way we tentatively identified a large number of triterpenoid saponins for the first time in HILIC UHPLC-MS, not previously reported in $G$. 
trichotoma. HILIC separation indicated a much broader range of GOTCAB than these in RP UHPLC-MS analysis due to the superior selectivity and peak capacity of this stationary phase. The proposed HILIC UHPLC method enabled the separation and identification of GOTCAB saponins with advantages in terms of selectivity in comparison with the relatively time consuming isolation and structure determination procedures typically employed for saponins. The analysis of HR-MS/MS data after HILIC UHPLC separation gave 21 saponins forming between 2 and 4 isobaric and positional isomers classified into three types of compounds depending of the type of substituent on the C-28 oligosaccharide, acyl and/or sulfate group. The type I is consistent with acylated GOTCAB saponins (1-8) from which 1a, 2a, 2b, 3a, 3c, 5a, 5c were identified as saponins references D, E, F, J, K, H and I, respectively. The type II sulfated GOTCAB saponins (9-15) were identified for the first time in this species and to our knowledge are not described in the literature. The type III - acylated and sulfated GOTCAB saponins (16-20) correspond to the saponin references A-C (16d, 16a, 16c) and their derivatives. Finally, compound 21a correspond to the non acylated and sulfated saponin reference $\mathbf{G}$, and $\mathbf{2 1 b}$ to its isomer isolated in G. paniculata (Frechet et al., 1991) and G. oldhamiana (Zhang et al., 2013).

Recently, new bidesmosides with an acetyl or a methoxycinnamoyl group at C-28 ester chain, as well as 3-O- $\beta$-sulfated monodesmosides were reported from the roots of some Gypsophila species (Krasteva et al., 2009; Yao et al., 2010; Luo et al., 1011). G. trichotoma is the only species with acetylated and sulfated GOTCAB saponins (Voutquenne-Nazabadioko et al., 2015). Four isobars (6a-6d) matched with compound 3 isolated from $G$. perfoliata (Chen et $a l ., 2011)$ and its isomers. It is consistent with our results from the previous study, where the saponin composition of Bulgarian G. trichotoma was very similar to those observed in $G$. perfoliata, originated from China (Voutquenne-Nazabadioko et al., 2015). In the UHPLC-MS analysis of GTR, two saponins at $m / z 1725.738$ (6a-6d) and 1525.669 [M-H] $^{-}(\mathbf{2 1 a}-21 d)$ were related to those reported in G. oldhamiana (Zhang et al., 2013), G. paniculata (Frechet et al.,1991) and G. perfoliata (Chen et al., 2011).

The selective profiling of GOTCAB presented here provides a base for more comprehensive survey of saponins distributed in Gypsophila species. These types of chemical inventories are necessary to understand the distribution and functional significance of saponins in plants and ultimately for future efforts to promote the health benefits of these medicinally important compounds. The combination of higher selective HILIC-UHPLC with HRMS and MS/MS detection enlarges the capabilities for recognition of new saponins.

\section{REFERENCES}

Arslan I., Celik A., Chol J.H. 2012. A cytotoxic triterpenoid saponin from underground parts of Gypsophila pilulifera Boiss.\& Heldr. Fitoterapia, 83: 699-703.

Arslan I., Celik A., Melzig M.F. 2013. Nebulosides A-B, novel triterpene saponins from under-ground parts of Gypsophila arrostii Guss. var. nebulosa. Bioorg. Med. Chem. 21: 1279-1283.

Bachran C, Bachran S, Sutherland M, Bachran D, Fuchs H. 2008. Saponins in tumor therapy. Mini Rev Med Chem 8:575-584.

Bai H., Zhong Y., Xie Y.Y., Wang Y.-S., Liu L., Zhou L. 2007. A major triterpenoid saponin from Gypsophila oldhamiana. Chem. Biodivers. 4: 955-60.

Bottger S, Melzig MF. 2010. Triterpenoid saponins of the Caryophyllaceae and Illecebraceae family. Phytochem Lett 4: 59-68. 
Bottger S, Westhof E, Siems K, Melzig MF. 2013. Structure-activity relationships of saponins enhancing the cytotoxicity of ribosome-inactivating proteins type I (RIP-I). Toxicon 73: $144-150$.

Chen Q, Luo JG, Kong LY. 2011. New triterpenoid saponins from the roots of Gypsophila perfoliata Linn. Carbohydr Res 346: 2206-2212.

Cheok CY, Salman HAK, Sulaiman R. 2014. Extraction and quantification of saponins: A review. Food Res Int 59: 16-40.

Francis G, Kerem Z, Makkar HP, Becker K. 2002. The biological action of saponins in animal systems: a review. Br J Nutr 88: 587-605.

Frechet, D., Christ, B., Monegier du Sorbier, B., Fisher, H., Vuilhorgne, M., 1991. Four triterpenoid saponins from dried roots of Gypsophila species. Phytochemistry 30: 927931.

Fuchs H, Bachran D, Panjideh H, Schellmann N, Weng A, Melzig MF; Sutherland M, Bachran C. 2009. Saponins as tool for improved targeted tumor therapies. Curr Drug Targets 10: $140-151$.

Gevrenova R, Weng A, Voutquenne-Nazabadioko L, Thakur M, Doytchinova I. 2015. QSAR study on saponins as cytotoxicity enhancers. Lett Drug Des Discov 12:166-171.

Gilabert-Oriol R, Mergel K, Thakur M, Mallinckrodt B, Melzig MF, Fuchs H, Weng A. 2013. Real-time analysis of membrane permeabilizing effects of oleanane saponins. Bioorg Med Chem. 21: 2387-2395.

Gilbert-Oriol R, Thakur M, Haussmann K, Niesler N, Bhargava C, Gorick C, Fuchs H, Weng A. 2016. Saponins from Saponaria officinalis L. augment the efficacy of rituximabimmunotoxin. Planta Med 82: 1525-1531.

Guo X, Zhang X. 2014. Hydrophilic interaction chromatography for selective separation of isomeric saponins. J Chromatogr A, 1325: 121-128.

Güçlü-Üstündag O, Mazza G. 2007. Saponins: properties, applications and processing. Crit Rev Food Sci Nutr 47: 231-258.

Henry M. 2005. Saponins and phylogeny: Example of the "Gypsogenin group" saponins. Phytochem Rev 4: 89-94.

Huang Y, Zhang T, Zhou H, FengY, Chunlin Fan Ch, Chen W, Jacques Crommen J, Jiang Z. 2016. Fast separation of triterpenoid saponins using SFC with single quadropole mass spectrometry. J Pharm Biomed Analysis, 121: 22-29.

Krasteva I, Jenett-Siems K, Kaloga M, Nikolov S. 2009. 3-O-Sulfo-triterpenoid saponins from Gypsophila trichotoma Wend. Z Naturforsch B 64: 319-322.

Luo J-G, Nie W, Kong L-Y. 2011. Three new sulfated triterpenoid from the roots of Gypsophila pacifica. J Asia Nat Prod Res 13:529-533.

Piorkowski DT, McClements DJ. 2014. Beverage emulsions: Recent developments in formulation, production, and applications. Food Hydrocoll 42: 5-41.

Podolak I, Galanty A, Sobolewska D. 2010. Saponins as cytotoxic agents: a review. Phytochem Rev 9:425-474.

Sandjo LP, dos Santos Nascimento MVP, da Silva LAL, Munhoz ACM, Pollo LAE, Biavatti MW, Ngadjui BT, Opatz T, Fröde TS. 2017. ESI-MS ${ }^{2}$ and Anti-inflammatory 
Studies of Cyclopropanic Triterpenes. UPLC-ESI-MS and MS $^{2}$ Search of Related Metabolites from Donella ubanguiensis. Phytochem Anal 28: 27-41.

Skene CD, Sutton P. 2006. Saponin-adjuvanted particulate vaccines for clinical use. Methods (San Diego, Calif.) 40: 53-59.

Vincken J-P, Heng L, de Groot A, Gruppen H. 2007. Saponins, classification and occurrence in the plant kingdom. Phytochemistry 68: 275-297.

Voutquenne-Nazabadioko L, Gevrenova R, Borie N, Harakat D, Sayagh Ch, Weng A, Thakur M, Zaharieva M, Henry M. 2013. Triterpenoid saponins from the roots of Gypsophila trichotoma Wender. Phytochemistry 90: 114-127.

Weng A. Melzig M.F. Bachran C. Fuchs, H. 2008. Enhancement of saporin toxicity against U937 cells by Gypsophila saponins. J. Immunotoxicol. 5: 287-292.

Xing Q, Liang T, Shen G, Wang X, Jin Y, Liang X. 2012. Comprehensive HILIC $\times$ RPLC with mass spectrometry detection for the analysis of saponins in Panax notoginseng. Analyst 137: 2239-2249.

Yao S, Ma L, Luo J-G, Wang J-S, Kong L-Y. 2010. New Triterpenoid Saponins from the Roots of Gypsophila paniculata L. Helv Chim Acta 93: 361-374.

Zhang W, Luo J-G, Zhang C, Kong L-Y. 2013. Different apoptotic effects of triterpenoid saponin-rich Gypsophila oldhamiana root extract on human hepatoma SMMC7721 and normal human hepatic L02 cells. Biol Pharm Bull 36: 1080-1087. 


\section{Figure captions}

Fig. 1. Chemical structure of GOTCAB saponin references.

Fig. 2. Extracted ion chromatograms of isobaric saponins with monoisotopic mass 1648.637 at $m / z$ of their $[\mathrm{M}-\mathrm{H}]^{-}$ion at negative ion mode $\left(\mathrm{a}_{1}\right)$ and $[\mathrm{M}+\mathrm{H}]^{+}$ion at positive ion mode $\left(\mathrm{b}_{1}\right)$ obtained by RP separation; (-) ESI-MS spectra of the peaks with retention time $13.84\left(\mathrm{a}_{2}\right)$ and $13.33\left(\mathrm{a}_{3}\right)$ on the chromatogram $\mathrm{a}_{1} ;(+)$ ESI-MS spectra of the peaks with retention time 14.62 $\left(b_{2}\right), 13.82\left(b_{3}\right), 13.35\left(b_{4}\right)$ and $12.68\left(b_{5}\right)$.Chromatographic conditions and injection volume were the same in both experiments.

Fig. 3. Comparison of reversed phase (RP) separation (chromatograms up) and hydrophilic interaction liquid chromatography (HILIC) separation (chromatograms down) of some $G$. trichotoma GOTCAB saponins by the extracted chromatograms at $m / z$ of their molecular [M$\mathrm{H}]^{-}$ions at negative ion mode of ESI-HRMS detection.

Fig. 4. Fragment MS/MS spectra of molecular $[\mathrm{M}-\mathrm{H}]^{-}$ion with $m / z=1647.637$ of the saponin A (Figure 1, Table 1) at higher energy collisional dissociation (hcd) $=20$ (a), hcd $=25$ (b) and hcd $=30(\mathrm{c})$ and hcd $=35(\mathrm{~d})$.

Fig. 5. Fragment MS/MS mass spectra of the molecular $[\mathrm{M}-\mathrm{H}]^{-}$ions of saponin references $\mathbf{A} \div \mathbf{G}$ in negative ion mode (Fig. 1, Table 1).

Fig. X. The fragmentation pattern of saponin reference D. Experimental values for fragment ions identified by ESI-HRMS/MS are presented in Table 1.

Fig. Y. The fragmentation pattern of reference A ester chain. Experimental values for fragment ions identified by ESI-HRMS/MS are presented in Table 1. 
Table 1. Fragmentation pattern of saponin references A-K*.

\begin{tabular}{|c|c|c|c|c|c|c|c|c|c|c|c|}
\hline $\begin{array}{c}\text { Saponin A } \\
\mathrm{C}_{72} \mathrm{H}_{112} \mathrm{O}_{40} \mathrm{~S}\end{array}$ & $\begin{array}{l}\text { Saponin B } \\
\mathrm{C}_{72} \mathrm{H}_{112} \mathrm{O}_{40} \mathrm{~S}\end{array}$ & $\begin{array}{l}\text { Saponin C } \\
\mathrm{C}_{72} \mathrm{H}_{112} \mathrm{O}_{40} \mathrm{~S}\end{array}$ & $\begin{array}{l}\text { Saponin D } \\
\mathrm{C}_{72} \mathrm{H}_{112} \mathrm{O}_{37}\end{array}$ & $\begin{array}{l}\text { Saponin E } \\
\mathrm{C}_{74} \mathrm{H}_{114} \mathrm{O}_{38}\end{array}$ & $\begin{array}{l}\text { Saponin F } \\
\mathrm{C}_{74} \mathrm{H}_{114} \mathrm{O}_{38}\end{array}$ & $\begin{array}{l}\text { Saponin G } \\
\mathrm{C}_{70} \mathrm{H}_{110} \mathrm{O}_{36}\end{array}$ & $\begin{array}{c}\text { Saponins } \\
\mathbf{H} / \mathbf{I} \\
\mathrm{C}_{79} \mathrm{H}_{122} \mathrm{O}_{42} \\
\end{array}$ & $\begin{array}{c}\text { Saponins } \\
\mathbf{J} / \mathbf{K} \\
\mathrm{C}_{80} \mathrm{H}_{118} \mathrm{O}_{38} \\
\end{array}$ & $\begin{array}{l}\text { MS-fragments } \\
\text { assignment:* }\end{array}$ & Formula & $\begin{array}{c}\text { Theoretical } \\
\text { mass }\end{array}$ \\
\hline & & & & & & & 1741.733 & & ${ }^{[\mathrm{M}-\mathrm{H}]^{-}}$ & $\mathrm{C}_{79} \mathrm{H}_{121} \mathrm{O}_{42}$ & 1741.7327 \\
\hline & & & & & & & 1699.725 & & {$[\mathrm{M}-\mathrm{H}-\mathrm{Ac}]^{-}$} & $\mathrm{C}_{77} \mathrm{H}_{119} \mathrm{O}_{41}$ & 1699.7221 \\
\hline & & & & & & & & 1685.723 & {$[\mathrm{M}-\mathrm{H}]^{-}$} & $\mathrm{C}_{80} \mathrm{H}_{117} \mathrm{O}_{38}$ & 1685.7217 \\
\hline \multirow[t]{2}{*}{1647.639} & 1647.6475 & 1647.638 & & & & & & & {$[\mathrm{M}-\mathrm{H}]^{-}$} & $\mathrm{C}_{72} \mathrm{H}_{111} \mathrm{O}_{40} \mathrm{~S}$ & 1647.6367 \\
\hline & & & & 1609.694 & 1609.693 & & 1609.693 & & $\begin{array}{l}{[\mathrm{M}-\mathrm{H}]^{-}} \\
{[\mathrm{M}-\mathrm{H}-\mathrm{Pent}]^{-}}\end{array}$ & $\mathrm{C}_{74} \mathrm{H}_{113} \mathrm{O}_{38}$ & 1609.6904 \\
\hline \multirow[t]{5}{*}{1567.671} & 1567.686 & 1567.702 & $1567.682(94.6)^{1}$ & 1567.679 & 1568.693 & & & & $\begin{array}{l}{[\mathrm{M}-\mathrm{H}]^{-}} \\
{\left[\mathrm{M}-\mathrm{H}-\mathrm{SO}_{3}\right]^{-}} \\
{[\mathrm{M}-\mathrm{H}-\mathrm{Ac}]^{-}}\end{array}$ & $\mathrm{C}_{72} \mathrm{H}_{111} \mathrm{O}_{37}$ & 1567.6799 \\
\hline & & & & & & & & 1553.680 & {$[\mathrm{M}-\mathrm{H}-\mathrm{Pent}]^{-}$} & $\mathrm{C}_{75} \mathrm{H}_{109} \mathrm{O}_{34}$ & 1553.6800 \\
\hline & & & $1525.677^{2}$ & & & 1525.670 & & & $\begin{array}{l}{[\mathrm{M}-\mathrm{H}]^{-}} \\
{[\mathrm{M}-\mathrm{H}-\mathrm{Acc}]^{-}={ }^{4} \mathrm{Y}_{0 \alpha}{ }^{2}}\end{array}$ & $\mathrm{C}_{70} \mathrm{H}_{109} \mathrm{O}_{36}$ & 1525.6693 \\
\hline & & & & & & & & 1523.669 & {$[\mathrm{M}-\mathrm{H}-\mathrm{Hex}]^{-}$} & $\mathrm{C}_{74} \mathrm{H}_{107} \mathrm{O}_{33}$ & 1523.6695 \\
\hline & & & & & & & & 1507.659 & ${\text { [M-H-MeCin }]^{-}}^{-}$ & $\mathrm{C}_{70} \mathrm{H}_{107} \mathrm{O}_{35}$ & 1507.6593 \\
\hline \multirow[t]{3}{*}{1485.600} & 1485.6026 & 1485.589 & & & & & & & {$[\mathrm{M}-\mathrm{H}-\mathrm{Hex}]^{-}$} & $\mathrm{C}_{66} \mathrm{H}_{101} \mathrm{O}_{35} \mathrm{~S}$ & 1485.5839 \\
\hline & & & & 1477.657 & 1477.667 & & & & ${ }^{[\mathrm{M}-\mathrm{H}-\mathrm{Pent}]^{-}}$ & $\mathrm{C}_{69} \mathrm{H}_{105} \mathrm{O}_{34}$ & 1477.6482 \\
\hline & & & 1435.650 & & & & & & {$[\mathrm{M}-\mathrm{H}-\text { Pent }]^{-}=\mathrm{Y}_{2 \alpha^{\prime}}$ or $\mathrm{Y}_{1 \beta^{\prime}}$} & $\mathrm{C}_{67} \mathrm{H}_{103} \mathrm{O}_{33}$ & 1435.6376 \\
\hline \multirow[t]{3}{*}{1405.633} & 1405.6240 & & 1405.632 & 1405.636 & 1405.637 & & & & $\begin{array}{l}{\left[\mathrm{M}-\mathrm{H}-\mathrm{Hex}-\mathrm{SO}_{3}\right]^{-}} \\
{[\mathrm{M}-\mathrm{H}-\mathrm{Hex}]^{-}=\mathrm{Y}_{2 \alpha} \text { or } \mathrm{Y}_{1 \beta}} \\
{[\mathrm{M}-\mathrm{H}-\mathrm{Hex}-\mathrm{Ac}]^{-}}\end{array}$ & $\mathrm{C}_{66} \mathrm{H}_{101} \mathrm{O}_{32}$ & 1405.6270 \\
\hline & & & & & & & 1187.580 & & {$[\mathrm{M}-\mathrm{H}-\mathrm{Chain} 1-2 \mathrm{Ac}]^{-}$} & $\mathrm{C}_{58} \mathrm{H}_{91} \mathrm{O}_{25}$ & 1187.5843 \\
\hline & & & 1237.565 & & & & & & $\begin{array}{l}{\left[\mathrm{M}-\mathrm{H}-\text { Pent-Hex-2 } \mathrm{H}_{2} \mathrm{O}\right]^{-}=} \\
\mathrm{Z}_{2 \alpha} / \mathrm{Z}_{2 \alpha^{\prime}}\end{array}$ & $\mathrm{C}_{61} \mathrm{H}_{89} \mathrm{O}_{26}$ & 1237.564 \\
\hline \multirow[t]{3}{*}{ 1177.511(19.1) } & 1177.516 & 1177.507 & & & & & & & {$[\mathrm{M}-\mathrm{H}-\mathrm{Ch} \text { ain } 1]^{-}$} & $\mathrm{C}_{55} \mathrm{H}_{85} \mathrm{O}_{25} \mathrm{~S}$ & 1177.5095 \\
\hline & & & 1127.528 & & & & & & {$[\mathrm{M}-\mathrm{H}-\mathrm{Pent}-\mathrm{dHex}-\mathrm{Hex}]^{-}=\mathrm{Y}_{1 \alpha}$} & $\mathrm{C}_{55} \mathrm{H}_{83} \mathrm{O}_{24}$ & 1127.5269 \\
\hline & & & 981.471 & & & & & & $\begin{array}{l}\text { [M-H-Pent-dHex-Hex-Ac- } \\
104]^{-}=\mathrm{Y}_{1 \alpha} /{ }^{0,2} \mathrm{X}_{0, \alpha}\end{array}$ & $\mathrm{C}_{49} \mathrm{H}_{73} \mathrm{O}_{20}$ & 981.469 \\
\hline 939.462 & 939.460 & 939.458 & 939.463(95.6) & 939.461 & 939.460 & 939.461 & 939.460 & 939.464 & {$[\mathrm{M}-\mathrm{H}-\mathrm{Chain} 2]^{-}=\mathrm{Y}_{0 \alpha}$} & $\mathrm{C}_{47} \mathrm{H}_{71} \mathrm{O}_{19}$ & 939.4584 \\
\hline \multirow[t]{3}{*}{807.414} & 807.417 & 807.420 & $807.421(4.6)$ & 807.418 & 807.417 & 807.418 & 807.418 & 807.418 & {$[\mathrm{M}-\mathrm{H}-\text { Chain2-Pent }]^{-}=\mathrm{Y}_{0 \alpha} / \mathrm{Y}_{1 \beta^{\prime}}$} & $\mathrm{C}_{42} \mathrm{H}_{63} \mathrm{O}_{15}$ & 807.4161 \\
\hline & & & & 789.409 & & 789.405 & & & $\mathrm{Y}_{0 \alpha}{ }^{0,1} \mathrm{X}_{1 \beta}$ & $\mathrm{C}_{42} \mathrm{H}_{61} \mathrm{O}_{14}$ & 789.4056 \\
\hline & & & & 777.398 & 777.408 & 777.408 & & & {$[\mathrm{M}-\mathrm{H}-\mathrm{Chain} 2-\mathrm{Hex}]^{-}=\mathrm{Y}_{0 \alpha} / \mathrm{Y}_{1 \beta}$} & $\mathrm{C}_{41} \mathrm{H}_{61} \mathrm{O}_{14}$ & $\ldots$ \\
\hline
\end{tabular}




\begin{tabular}{|c|c|c|c|c|c|c|c|c|c|c|c|}
\hline \multirow[t]{5}{*}{759.383} & 759.397 & 759.398 & $759.397(15.2)$ & 759.398 & 759.397 & 759.397 & 759.393 & 759.403 & $\begin{array}{l}{\left[\mathrm{M}-\mathrm{H}-\mathrm{Ch} \text { ain2-Hex- } \mathrm{H}_{2} \mathrm{O}\right]^{-}=} \\
\mathrm{Y}_{0 \alpha} / \mathrm{Z}_{1 \beta}\end{array}$ & $\mathrm{C}_{41} \mathrm{H}_{59} \mathrm{O}_{13}$ & 759.3950 \\
\hline & & & & & & & & 745.263 & [Chain2-H] $^{-}$ & $\mathrm{C}_{33} \mathrm{H}_{45} \mathrm{O}_{19}$ & 745.2633 \\
\hline & & & $745.417(8.4)$ & 745.417 & 745.419 & 745.419 & & & $\begin{array}{l}{\left[\mathrm{M}-\mathrm{H}-\mathrm{Chain} 2-\text { Pent- } \mathrm{H}_{2} \mathrm{O}-\mathrm{CO}_{2}\right]^{-}} \\
=\mathrm{Y}_{0 \alpha} / \mathrm{Z}_{1 \beta^{\prime}} / \mathrm{CO}_{2}\end{array}$ & $\mathrm{C}_{41} \mathrm{H}_{61} \mathrm{O}_{12}$ & 745.416 \\
\hline & & & 727.410 & 727.409 & 727.406 & 727.406 & & & $\begin{array}{l}{\left[\mathrm{M}-\mathrm{H}-\mathrm{Chain} 2-\text { Pent- } 2 \mathrm{H}_{2} \mathrm{O}-\right.} \\
\left.\mathrm{CO}_{2}\right]^{-}= \\
\mathrm{Y}_{0 \alpha} / \mathrm{Z}_{1 \beta^{\prime}} / \mathrm{H}_{2} \mathrm{O} / \mathrm{CO}_{2}\end{array}$ & $\mathrm{C}_{41} \mathrm{H}_{59} \mathrm{O}_{11}$ & 727.4052 \\
\hline & & & & & 715.411 & & & & $\begin{array}{l}\text { [M-H-Chain2-Pent- } \mathrm{H}_{2} \mathrm{O}-\mathrm{CO}_{2-} \\
30]^{-}=\mathrm{Y}_{0 \alpha} / \mathrm{Z}_{1 \beta} / \mathrm{CO}_{2} /{ }^{2,3} \mathrm{X}_{1 \beta}\end{array}$ & $\mathrm{C}_{40} \mathrm{H}_{59} \mathrm{O}_{11}$ & 715.4052 \\
\hline \multirow[t]{3}{*}{$707.172(100)$} & 707.1726 & 707.172 & & & & & & & [Chain2-H] $^{-}$ & $\mathrm{C}_{25} \mathrm{H}_{39} \mathrm{O}_{21} \mathrm{~S}$ & 707.1700 \\
\hline & & & & & 697.401 & & & & $\begin{array}{l}{\left[\mathrm{M}-\mathrm{H}-\mathrm{C} \text {-Chain2-Pent- } 2 \mathrm{H}_{2} \mathrm{O}-\mathrm{CO}_{2^{-}}\right.} \\
30]^{-}=\mathrm{Y}_{0 \alpha} / \mathrm{Z}_{1 \beta} / \mathrm{H}_{2} \mathrm{O} / \mathrm{CO}_{2} /{ }^{2,3} \mathrm{X}_{1 \beta}\end{array}$ & $\mathrm{C}_{40} \mathrm{H}_{57} \mathrm{O}_{10}$ & 697.3946 \\
\hline & & & & & 673.395 & & & & $\begin{array}{l}\text { [M-H-Chain2-Pent- } \mathrm{H}_{2} \mathrm{O}-\mathrm{CO}_{2-} \\
72]^{-}=\mathrm{Y}_{0 \alpha} / \mathrm{Z}_{1 \beta} / \mathrm{CO}_{2} /{ }^{0,3} \mathrm{X}_{1 \beta}\end{array}$ & $\mathrm{C}_{38} \mathrm{H}_{57} \mathrm{O}_{10}$ & 673.395 \\
\hline \multirow[t]{4}{*}{$647.152(11.3)$} & 647.151 & 647.154 & & & & & & & [Chain2-H-AcOH] $^{-}$ & $\mathrm{C}_{23} \mathrm{H}_{35} \mathrm{O}_{19} \mathrm{~S}$ & 647.1488 \\
\hline & & & & & 645.359 & & & & $\begin{array}{l}{[\mathrm{M}-\mathrm{H}-\mathrm{Chain} 2-\mathrm{Pent}-\mathrm{Hex}]^{-}=} \\
\mathrm{Y}_{0 \alpha} / \mathrm{Y}_{1 \beta} / \mathrm{Y}_{1 \beta^{\prime}}\end{array}$ & & 645.363 \\
\hline & & & 627.354 & 627.3571 & 627.354 & 627.354 & & & $\begin{array}{l}\left.\text { [M-H-Chain2-Pent-Hex-H } \mathrm{H}_{2} \mathrm{O}\right]^{-} \\
=\mathrm{Y}_{0 \alpha} / \mathrm{Z}_{1 \beta^{\prime}} / \mathrm{Y}_{1 \beta} \text { or } \mathrm{Y}_{0 \alpha} / \mathrm{Z}_{1 \beta} / \mathrm{Y}_{1 \beta^{\prime}}\end{array}$ & $\mathrm{C}_{36} \mathrm{H}_{51} \mathrm{O}_{9}$ & 627.3528 \\
\hline & & & $609.344(5.02)$ & 609.343 & 609.343 & 609.344 & & & $\begin{array}{l}{[\mathrm{M}-\mathrm{H}-\mathrm{Chain} 2-\mathrm{Pent}-\mathrm{Hex}-} \\
\left.2 \mathrm{H}_{2} \mathrm{O}\right]^{-}=\mathrm{Y}_{0 \alpha} / \mathrm{Z}_{1 \beta} / \mathrm{Z}_{1 \beta^{\prime}}\end{array}$ & $\mathrm{C}_{36} \mathrm{H}_{49} \mathrm{O}_{8}$ & 609.3422 \\
\hline $607.119(10.5)$ & 607.119 & & & & & & & & ${ }^{3,5} \mathrm{X}_{0 \alpha}{ }^{3}$ & $\mathrm{C}_{20} \mathrm{H}_{31} \mathrm{O}_{19} \mathrm{~S}$ & \\
\hline $591.126(8.3)$ & 591.123 & & & & & & & & $0,3 \mathrm{X}_{0 \alpha}$ & $\mathrm{C}_{20} \mathrm{H}_{31} \mathrm{O}_{18} \mathrm{~S}$ & 591.123 \\
\hline 583.366 & 583.363 & 583.366 & 583.366 18.5) & 583.365 & 583.365 & 583.365 & 583.364 & 583.367 & $\begin{array}{l}\text { [M-H-Chain2-Pent-Hex-H } \mathrm{H}_{2} \mathrm{O}- \\
\left.\mathrm{CO}_{2}\right]^{-}=\mathrm{Y}_{0 \alpha} / \mathrm{Z}_{1 \beta} / \mathrm{Y}_{1 \beta} / \mathrm{CO}_{2}\end{array}$ & $\mathrm{C}_{35} \mathrm{H}_{51} \mathrm{O}_{7}$ & 583.3629 \\
\hline 579.124 & 579.124 & & & & & & & & ${ }^{1,3} \mathrm{X}_{0 \alpha}$ & $\mathrm{C}_{19} \mathrm{H}_{31} \mathrm{O}_{18} \mathrm{~S}$ & $\ldots$ \\
\hline \multirow[t]{4}{*}{565.351} & 565.352 & 565.356 & $565.354(39.7)$ & 565.354 & 565.354 & 565.354 & 565.354 & 565.354 & $\begin{array}{l}\text { [M-H-Chain2-Pent-Hex-2 } \mathrm{H}_{2} \mathrm{O}- \\
\left.\mathrm{CO}_{2}\right]^{-}=\mathrm{Y}_{0 \alpha} / \mathrm{Z}_{1 \beta} / \mathrm{Z}_{1 \beta} / \mathrm{CO}_{2}\end{array}$ & $\mathrm{C}_{35} \mathrm{H}_{49} \mathrm{O}_{6}$ & 565.3524 \\
\hline & & & $551.338(26.0)$ & 551.338 & 551.338 & 551.338 & 551.338 & 551.340 & $\begin{array}{l}{\left[\mathrm{M}-\mathrm{H}-\mathrm{Chain} 2-\mathrm{Pent}-\mathrm{Hex}-2 \mathrm{H}_{2} \mathrm{O}-\right.} \\
58]^{-}=\mathrm{Y}_{0 \alpha} / \mathrm{Z}_{1 \beta} / \mathrm{Z}_{1 \beta} /^{4,5} \mathrm{~A}_{0 \beta}\end{array}$ & $\mathrm{C}_{35} \mathrm{H}_{47} \mathrm{O}_{6}$ & 551.337 \\
\hline & & & $547.343(8.0)$ & 547.342 & 547.342 & 547.343 & 547.343 & 547.343 & $\begin{array}{l}\text { [M-H-Chain2-Pent-Hex-3 } \mathrm{H}_{2} \mathrm{O} \text { - } \\
\left.\mathrm{CO}_{2}\right]^{-}=\mathrm{Y}_{0 \alpha} / \mathrm{Z}_{1 \beta} / \mathrm{Z}_{1 \beta} / \mathrm{H}_{2} \mathrm{O} / \mathrm{CO}_{2}\end{array}$ & $\mathrm{C}_{35} \mathrm{H}_{47} \mathrm{O}_{5}$ & 547.3418 \\
\hline & & & $537.360(8.8)$ & 537.359 & 537.359 & 537.359 & & & $\begin{array}{l}\text { [M-H-Chain2-Pent-Hex- } \mathrm{H}_{2} \mathrm{O}- \\
\left.\mathrm{HCO}_{2} \mathrm{H}-\mathrm{CO}_{2}\right]^{-}= \\
\mathrm{Y}_{0 \alpha} / \mathrm{Y}_{1 \beta} / / \mathrm{H}_{2} \mathrm{O} / \mathrm{HCO}_{2} \mathrm{H} / \mathrm{CO}_{2}\end{array}$ & $\mathrm{C}_{34} \mathrm{H}_{49} \mathrm{O}_{5}$ & 537.3596 \\
\hline $527.161(3.7)$ & 527.163 & & & & & & & & $\mathrm{X}_{2 \alpha} / /^{3,5} \mathrm{X}_{0 \alpha}$ & $\mathrm{C}_{20} \mathrm{H}_{31} \mathrm{O}_{16}$ & 527.161 \\
\hline
\end{tabular}




\begin{tabular}{|c|c|c|c|c|c|c|c|c|c|c|c|}
\hline & & & $519.348(2.07)$ & 519.347 & 519.350 & 519.348 & & & $\begin{array}{l}\text { [M-H-Chain2-Pent-Hex-2 } \mathrm{H}_{2} \mathrm{O}- \\
\left.\mathrm{HCO}_{2} \mathrm{H}-\mathrm{CO}_{2}\right]^{-}= \\
\mathrm{Y}_{0 \alpha} / \mathrm{Z}_{1 \beta} / \mathrm{Y}_{1 \beta} / 2 \mathrm{H}_{2} \mathrm{O} / \mathrm{HCO}_{2} \mathrm{H} / \mathrm{CO}_{2}\end{array}$ & $\mathrm{C}_{34} \mathrm{H}_{47} \mathrm{O}_{4}$ & 519.3469 \\
\hline \multirow[t]{2}{*}{$519.103(29.2)$} & 519.103 & 519.103 & & & & & & & {$[\text { Chain2-H-dHex-Ac] }]^{-}=\mathrm{C}_{1 \alpha}$} & $\mathrm{C}_{17} \mathrm{H}_{27} \mathrm{O}_{16} \mathrm{~S}$ & 519.1014 \\
\hline & & & $511.344(4.1)$ & 511.344 & 511.345 & 511.343 & & & $\begin{array}{l}{[\mathrm{M}-\mathrm{H}-\mathrm{Chain} 2-\mathrm{Pent}-\mathrm{Hex}-134]^{-}} \\
=\mathrm{Y}_{0 \alpha}{ }^{0,2} \mathrm{X}_{0 \beta} / \mathrm{Y}_{1 \beta}\end{array}$ & $\mathrm{C}_{32} \mathrm{H}_{47} \mathrm{O}_{5}$ & 511.342 \\
\hline \multirow[t]{2}{*}{\begin{tabular}{|l|}
$503.108(9.8)$ \\
\end{tabular}} & 503.109 & & & & & & & & $\mathrm{Y}_{2 \alpha^{\prime}}{ }^{\beta, 4} \mathrm{X}_{0 \alpha}$ & $\mathrm{C}_{17} \mathrm{H}_{27} \mathrm{O}_{15} \mathrm{~S}$ & 503.108 \\
\hline & & & $495.348(2.3)$ & 495.347 & & 495.350 & & & $\mathrm{Y}_{0 \alpha} /{ }^{0,2} \mathrm{X}_{0 \beta} / \mathrm{Z}_{1 \beta}$ & $\mathrm{C}_{32} \mathrm{H}_{47} \mathrm{O}_{4}$ & 495.3469 \\
\hline $469.332(5.8)$ & 469.333 & 469.332 & $469.332(100)$ & 469.333 & 469.333 & 469.332 & 469.332 & 469.332 & [gypsognin-H] $^{-}$ & $\mathrm{C}_{30} \mathrm{H}_{45} \mathrm{O}_{4}$ & 469.3312 \\
\hline \multirow[t]{4}{*}{451.325} & 451.325 & 451.321 & $451.324(22.1)$ & 451.322 & 451.322 & 451.322 & 451.322 & 451.321 & [gypsognin- $\left.\mathrm{H}_{-} \mathrm{H}_{2} \mathrm{O}\right]^{-}$ & $\mathrm{C}_{30} \mathrm{H}_{43} \mathrm{O}_{3}$ & 451.3207 \\
\hline & & & 439.323 & 439.324 & 439.322 & 439.322 & 439.321 & 439.323 & 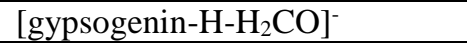 & $\mathrm{C}_{29} \mathrm{H}_{43} \mathrm{O}_{3}$ & 439.3207 \\
\hline & 423.327 & & $423.328(13.3)$ & 423.328 & 423.327 & 423.328 & 423.327 & 423.328 & ${\left.\text { [gypsogenin- } \mathrm{H}-\mathrm{HCO}_{2} \mathrm{H}\right]^{-}}^{-}$ & $\mathrm{C}_{29} \mathrm{H}_{43} \mathrm{O}_{2}$ & 423.3258 \\
\hline & & & 405.317 & 405.316 & 405.315 & 405.316 & & & {$\left[\text { gypsogenin- } \mathrm{H}-\mathrm{HCO}_{2} \mathrm{H}-\mathrm{H}_{2} \mathrm{O}\right]^{-}$} & $\mathrm{C}_{29} \mathrm{H}_{41} \mathrm{O}$ & 405.3152 \\
\hline $371.065(4.2)$ & 371.065 & 371.063 & & & & & & & $\mathrm{Y}_{2 \alpha^{\prime}} / \mathrm{C}_{1 \alpha}$ & $\mathrm{C}_{12} \mathrm{H}_{19} \mathrm{O}_{11} \mathrm{~S}$ & 371.064 \\
\hline 329.019 & 329.019 & 329.018 & & & & & & & ${ }^{3,5} \mathrm{X}_{1 \alpha} / \mathrm{C}_{1 \alpha}$ & $\mathrm{C}_{9} \mathrm{H}_{13} \mathrm{O}_{11} \mathrm{~S}$ & 329.022 \\
\hline 301.024 & 301.025 & & & & & & & & $\mathrm{Y}_{2 \alpha^{\prime}} / \mathrm{C}_{1 \alpha}$ & $\mathrm{C}_{8} \mathrm{H}_{13} \mathrm{O}_{10} \mathrm{~S}$ & 301.022 \\
\hline $259.013(8.0)$ & 259.013 & $259 . .014$ & & & & & & & $\mathrm{C}_{2 \alpha}$ & $\mathrm{C}_{6} \mathrm{H}_{11} \mathrm{O}_{9} \mathrm{~S}$ & 259.012 \\
\hline $241.002(17.0)$ & 241.002 & 241.002 & & & & & & & 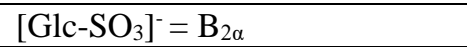 & $\mathrm{C}_{6} \mathrm{H}_{9} \mathrm{O}_{8} \mathrm{~S}$ & 241.0013 \\
\hline
\end{tabular}

$* \mathrm{Hex}=$ hexose, Pent $=$ pentose, $\mathrm{dHex}=$ deoxyhexose, $\mathrm{HexA}=$ hexosuronic acid $; \mathrm{SO}_{3}=$ sulfate group,

$\mathrm{Ac}=$ acetyl group, MeCin, methoxycinnamoyl group; Chain $1=\mathrm{C}-3$ trisaccharide chain, Chain $2=\mathrm{C}-28$ ester chain

${ }^{1}$ relative abundance

${ }^{2}$ fragments are related to saponin reference D (Fig. X)

${ }^{3}$ fragments are related to saponin reference A (Fig.Y) 
Table 2. Tentative assignment of GOTCAB saponins from G. trichotoma roots (GTR) by MS and MS/MS data.

\begin{tabular}{|c|c|c|c|c|c|c|c|c|c|}
\hline \multirow{3}{*}{$\begin{array}{l}\text { Order No } \\
\text { of the } \\
\text { separated } \\
\text { saponins }\end{array}$} & \multirow{3}{*}{$\begin{array}{c}{[\mathrm{m} / \mathrm{z}]} \\
\text { of the } \\
\text { molecular } \\
{[\mathrm{M}-\mathrm{H}]^{-}} \\
\text {ion } \\
\text { (measured) }\end{array}$} & \multicolumn{3}{|c|}{$\begin{array}{l}\text { Number of the } \\
\text { separated isobaric } \\
\text { isomers }\end{array}$} & \multirow{3}{*}{$\begin{array}{c}\text { MS/MS } \\
\text { fragments } \\
\text { of the main } \\
\text { isomer } \\
{[\mathrm{m} / z]}\end{array}$} & \multicolumn{2}{|c|}{ Interpretation of the structure } & \multirow{3}{*}{$\begin{array}{c}{[\mathrm{m} / \mathrm{z}]} \\
\text { of the molecular } \\
{[\mathrm{M}-\mathrm{H}]^{-}} \\
\text {ion } \\
\text { (calculated) }\end{array}$} & \multirow{3}{*}{$\begin{array}{c}\text { Formula } \\
\text { and } \\
\text { monoisotopic } \\
\text { mass } \\
\text { (calculated) }\end{array}$} \\
\hline & & $\begin{array}{l}\text { by } \\
\text { RP }\end{array}$ & & $\begin{array}{l}\text { by } \\
\text { ILIC }\end{array}$ & & \multirow{2}{*}{ Fragments } & \multirow{2}{*}{ Tentative structure } & & \\
\hline & & total & total & $\mathrm{t}_{\mathrm{r}}[\mathrm{min}]$ & & & & & \\
\hline
\end{tabular}




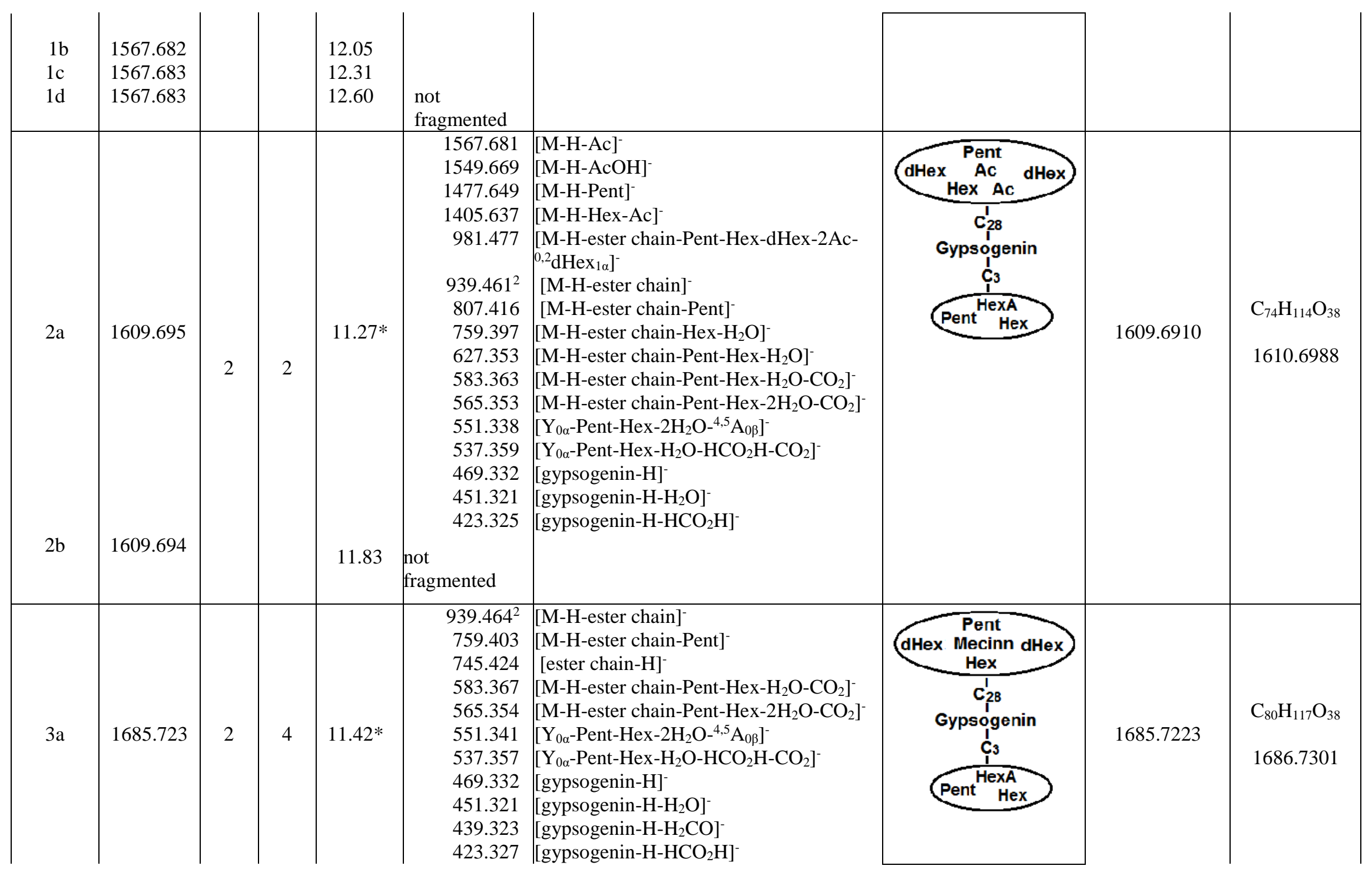




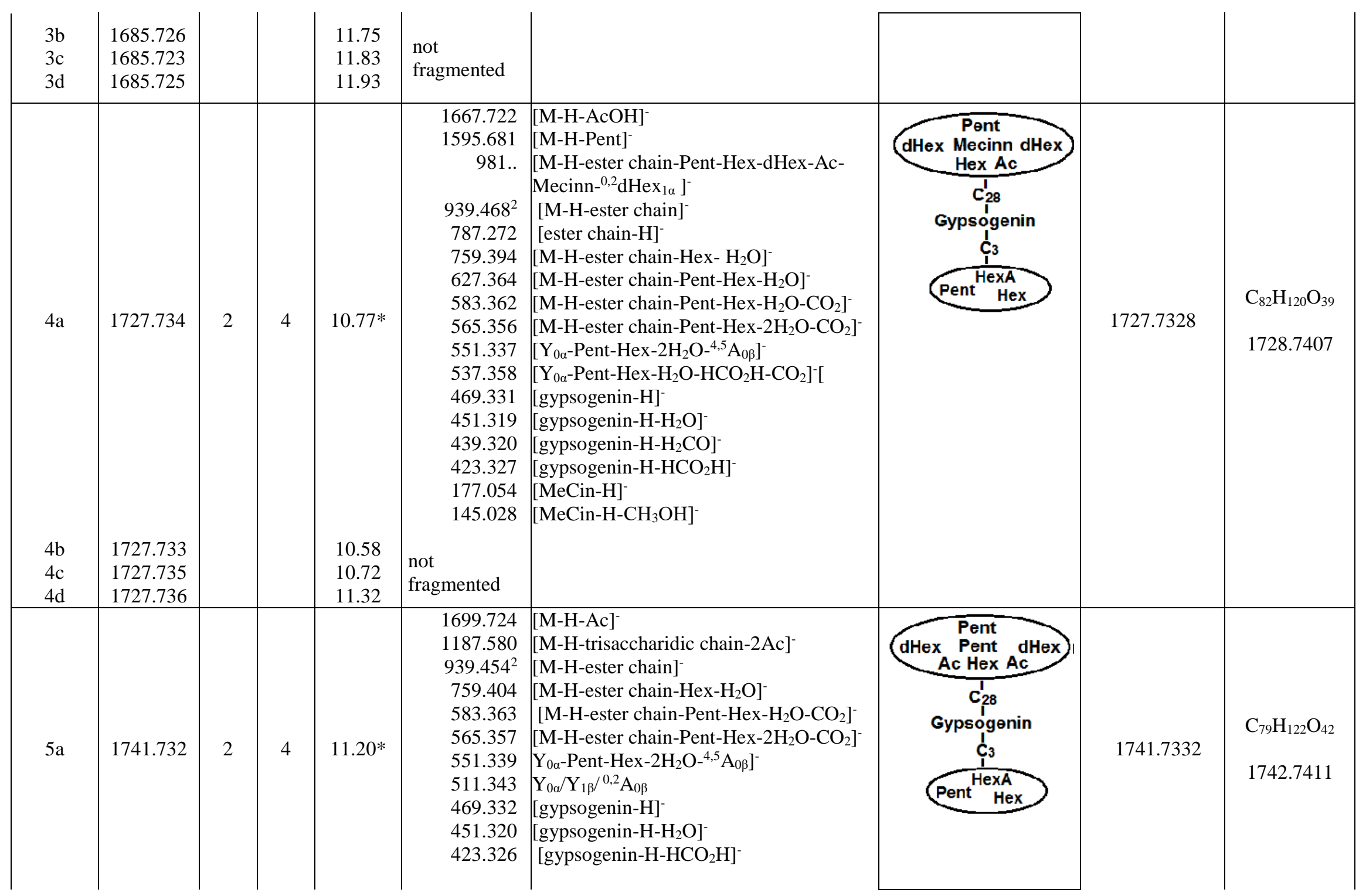




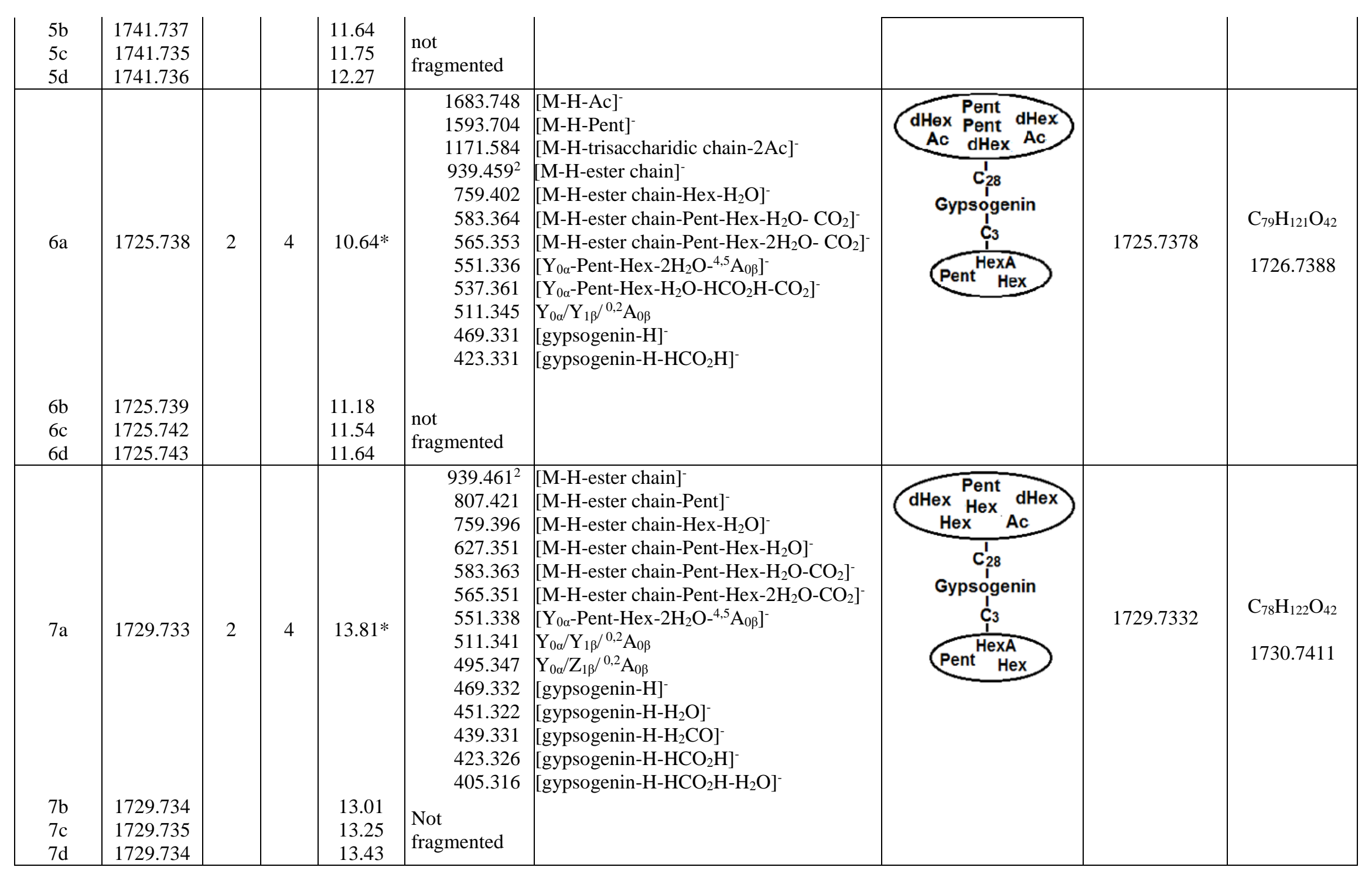




\begin{tabular}{|c|c|c|c|c|c|c|c|c|c|}
\hline $\begin{array}{l}8 \mathrm{~b} \\
8 \mathrm{c} \\
8 \mathrm{~d}\end{array}$ & $\begin{array}{l}1435.641 \\
\\
\\
\\
1435.639 \\
1435.638 \\
1435.638\end{array}$ & 2 & 4 & $\begin{array}{l}11.39 * \\
\\
\\
\\
\\
11.27 \\
11.57 \\
11.95\end{array}$ & \begin{tabular}{|r}
$939.450^{2}$ \\
759.395 \\
627.350 \\
583.366 \\
565.353 \\
551.337 \\
537.358 \\
511.342 \\
495.349 \\
469.332 \\
451.321 \\
439.323 \\
423.327 \\
405.314 \\
not \\
fragmented
\end{tabular} & 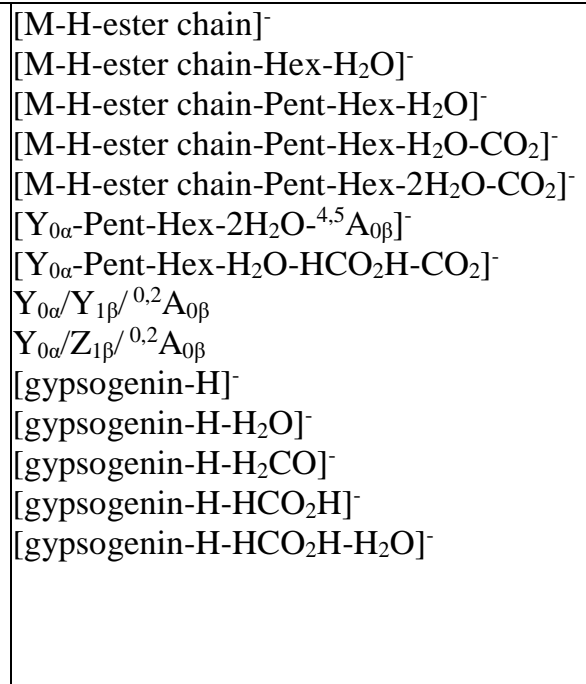 & 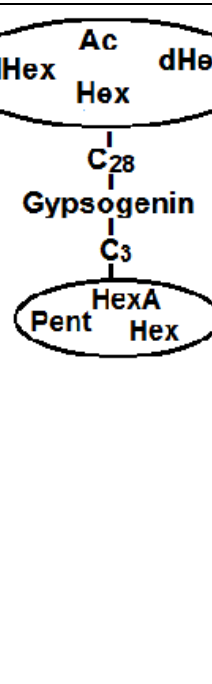 & 1435.6382 & $\begin{array}{l}\mathrm{C}_{67} \mathrm{H}_{104} \mathrm{O}_{33} \\
1436.6460\end{array}$ \\
\hline $9 a$ & $\begin{array}{l}1605.628 \\
1605.627\end{array}$ & 1 & 2 & $\begin{array}{r}11.42 * \\
\\
10.98\end{array}$ & $\begin{array}{r}1525.680 \\
1135.498 \\
939.461 \\
665.160 \\
607.118 \\
579.124 \\
527.162 \\
519.102 \\
503.108 \\
469.331 \\
451.322 \\
423.331 \\
371.066 \\
329.018 \\
301.022 \\
259.012 \\
241.102 \\
\text { not }\end{array}$ & 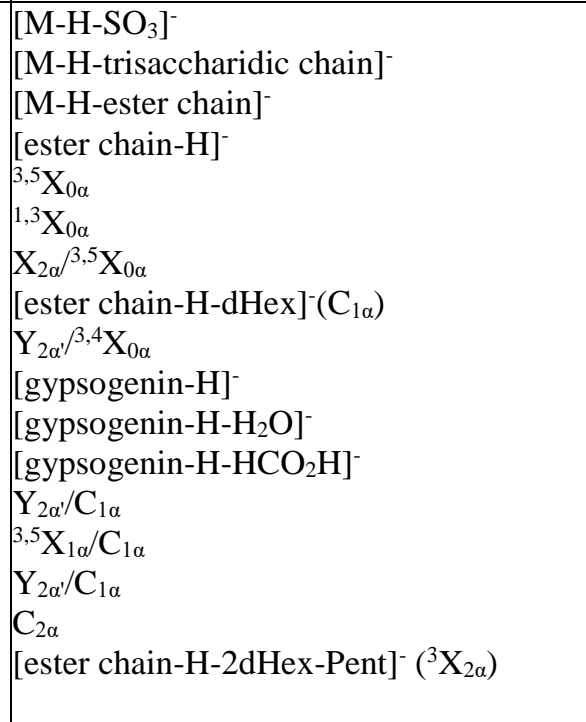 & $\begin{array}{c}C_{28}^{I} \\
\text { Gypsogen } \\
C_{3} \\
\end{array}$ & 1605.6267 & $\begin{array}{c}\mathrm{C}_{70} \mathrm{H}_{110} \mathrm{O}_{39} \mathrm{~S} \\
1606,6345\end{array}$ \\
\hline
\end{tabular}




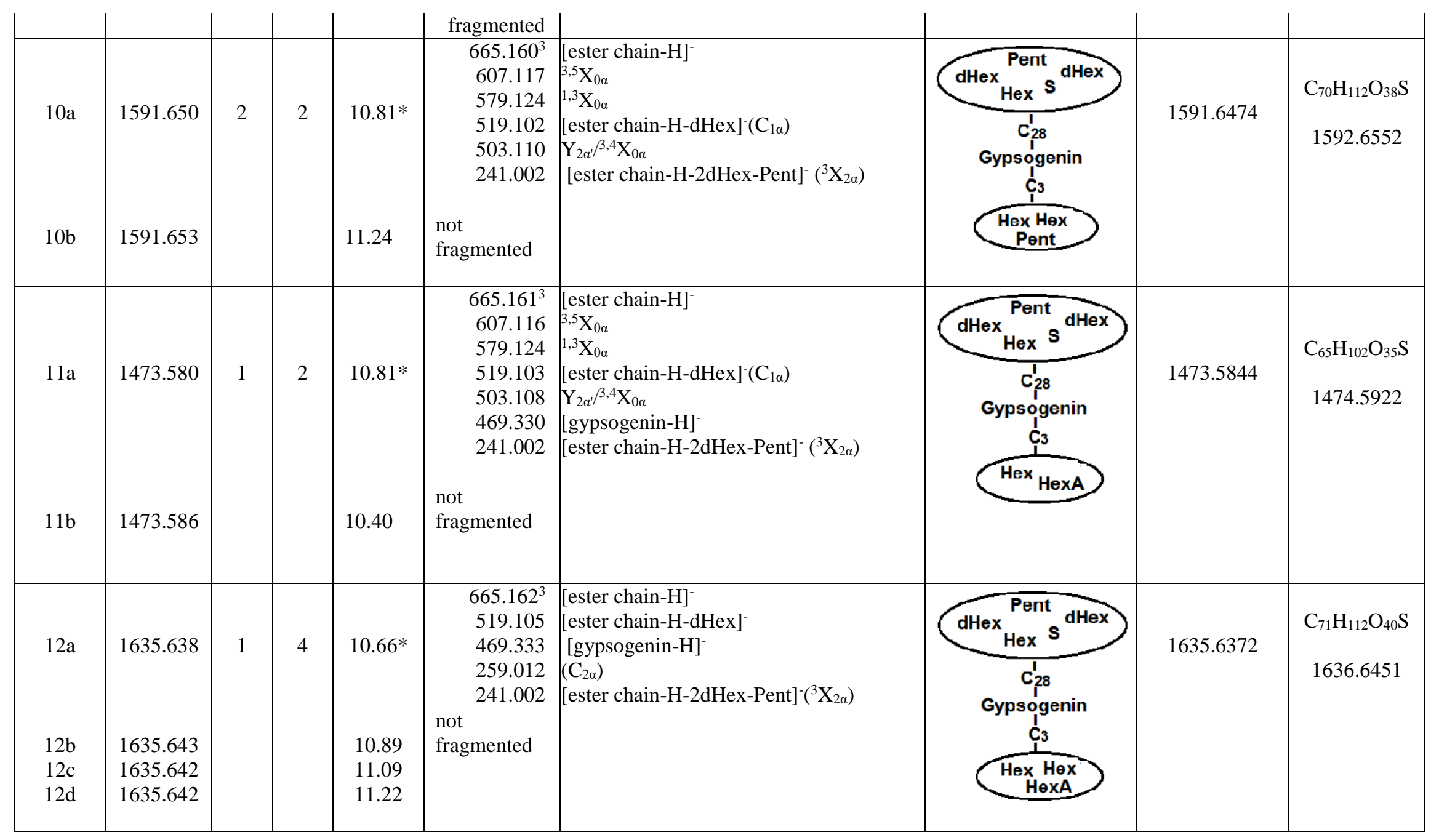




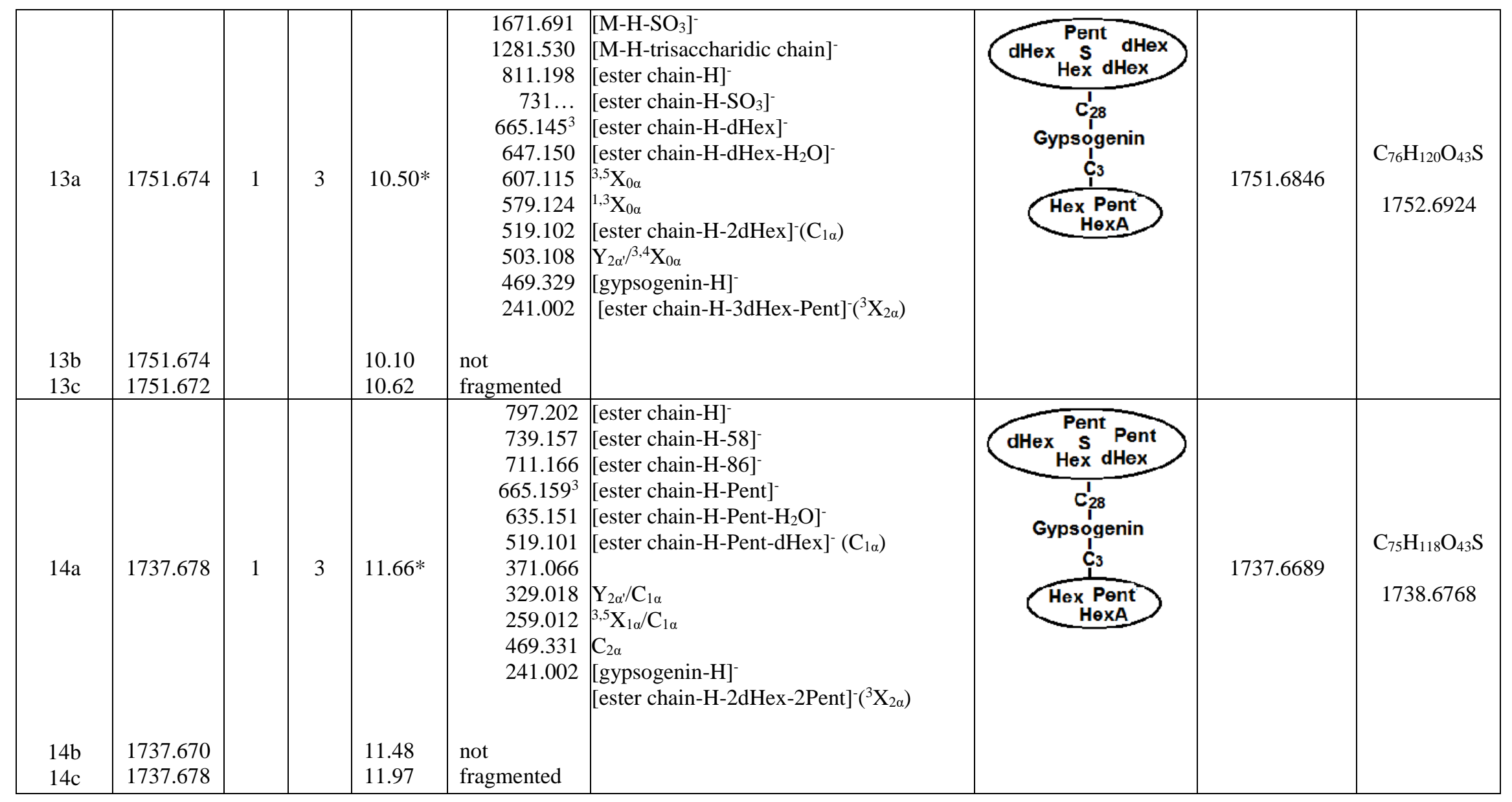




\begin{tabular}{|c|c|c|c|c|c|c|c|c|c|}
\hline $\begin{array}{l}15 b \\
15 c\end{array}$ & $\begin{array}{r}1767.686 \\
\\
1767.685 \\
1767.681\end{array}$ & 3 & 3 & $\begin{array}{l}12.10^{*} \\
\\
\\
\\
12.25 \\
12.72 \\
\end{array}$ & $\begin{array}{r}1687.726 \\
1297.556 \\
939.444 \\
827.215 \\
665.162^{3} \\
607.119 \\
579.123 \\
519.104 \\
503.109 \\
469.335 \\
241.002 \\
\text { not } \\
\text { fragmented }\end{array}$ & 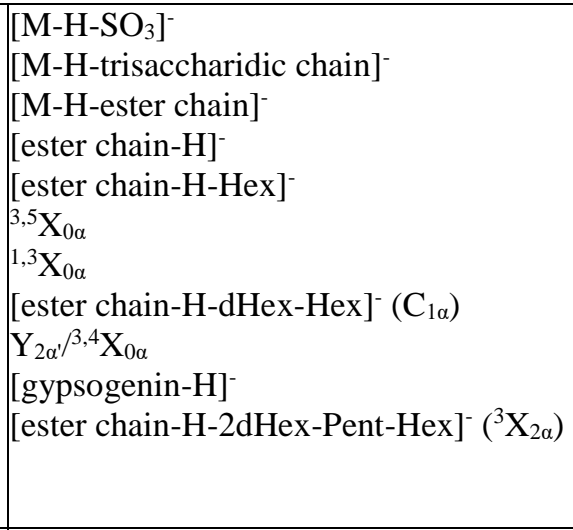 & 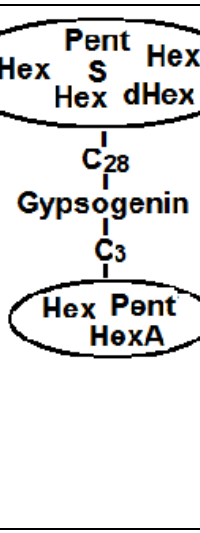 & 1767.6795 & $\begin{array}{r}\mathrm{C}_{76} \mathrm{H}_{120} \mathrm{O}_{44} \mathrm{~S} \\
1768.6873\end{array}$ \\
\hline $16 \mathrm{a}$ & 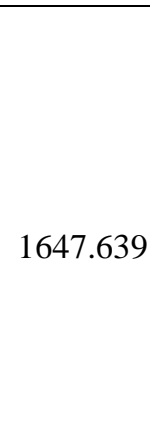 & 3 & 4 & $11.03^{*}$ & $\begin{array}{r}1177.510 \\
939.464 \\
759.395 \\
707.171^{3} \\
607.118 \\
579.124 \\
519.102 \\
503.108 \\
469.332 \\
451.321 \\
241.002\end{array}$ & 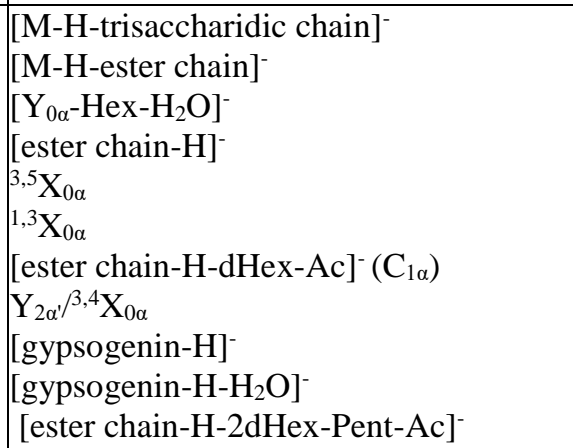 & $\begin{array}{c}C_{28}^{\top} \\
\text { Gypsogenin } \\
C_{3}^{\prime} \\
\end{array}$ & 1647.6372 & $\begin{array}{c}\mathrm{C}_{72} \mathrm{H}_{112} \mathrm{O}_{40} \mathrm{~S} \\
1648,6451\end{array}$ \\
\hline $\begin{array}{l}16 \mathrm{~b} \\
16 \mathrm{c} \\
16 \mathrm{~d}\end{array}$ & $\begin{array}{l}1647.639 \\
1647.638 \\
1647.639\end{array}$ & & & $\begin{array}{l}10.43 \\
10.59 \\
10.87\end{array}$ & $\begin{array}{l}\text { not } \\
\text { fragmented }\end{array}$ & & & & \\
\hline
\end{tabular}




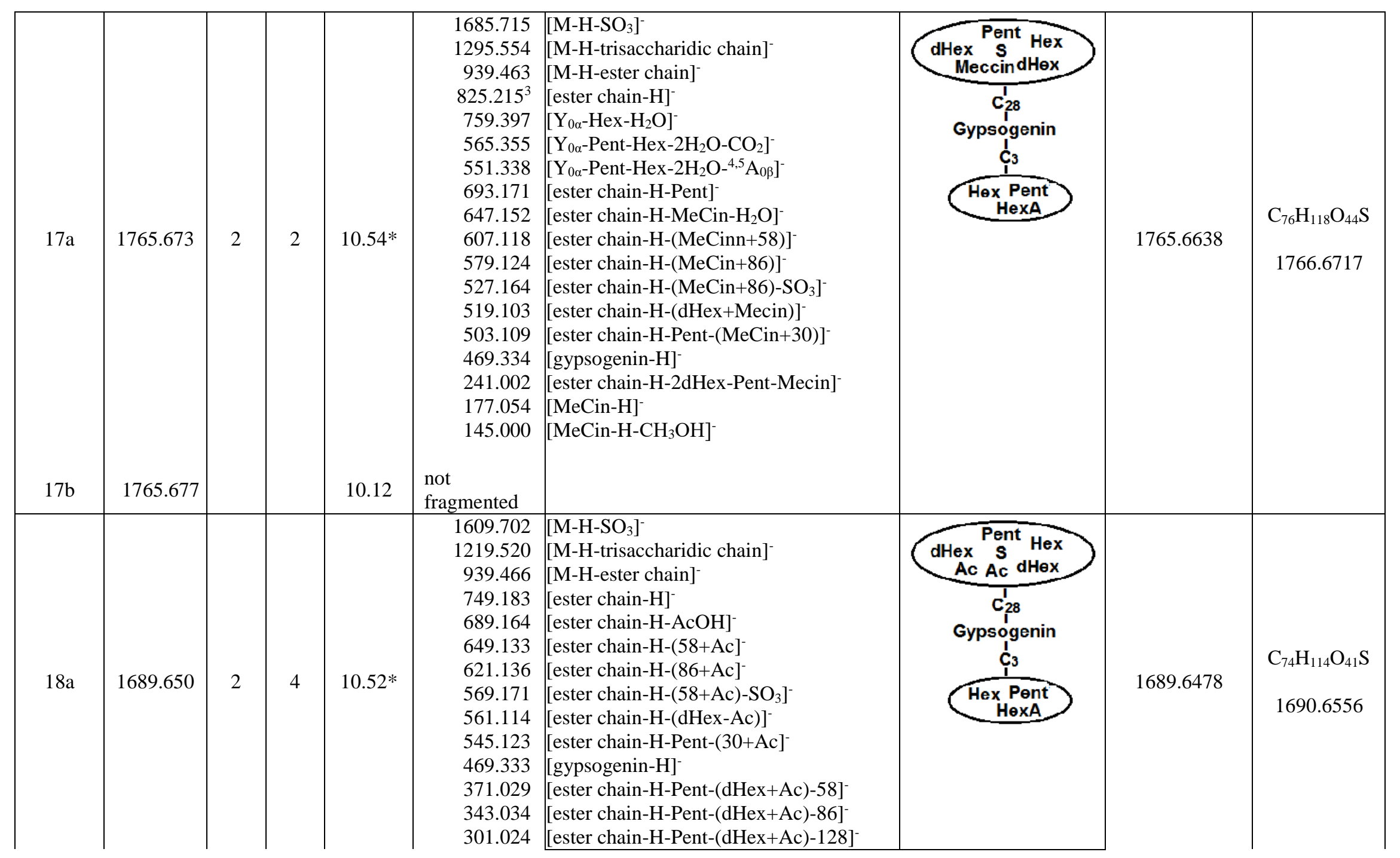




\begin{tabular}{|c|c|c|c|c|c|c|c|c|c|}
\hline $\begin{array}{l}18 \mathrm{~b} \\
18 \mathrm{c} \\
18 \mathrm{~d} \\
\end{array}$ & $\begin{array}{l}1689.651 \\
1689.651 \\
1689.653 \\
\end{array}$ & & & $\begin{array}{l}10.08 \\
10.72 \\
10.91 \\
\end{array}$ & $\begin{array}{l}283.013 \\
241.002 \\
\\
\text { not } \\
\text { fragmented }\end{array}$ & \begin{tabular}{|l}
{$\left[\text { ester chain-H-Pent- }(\mathrm{dHex}+\mathrm{Ac})-\mathrm{H}_{2} \mathrm{O}-86\right]^{-}$} \\
{$\left[\right.$ester chain-H-2dHex-Pent-2Ac] $^{-}$}
\end{tabular} & & & \\
\hline . & 1779.679 & 2 & 3 & $11.27 *$ & $\begin{array}{r}1699.724 \\
1647.628 \\
1537.645 \\
1309.552 \\
939.462^{2} \\
839.212 \\
779.196 \\
739.161 \\
707.171^{3} \\
651.148 \\
635.151 \\
609.345 \\
519.104 \\
469.333 \\
241.001\end{array}$ & 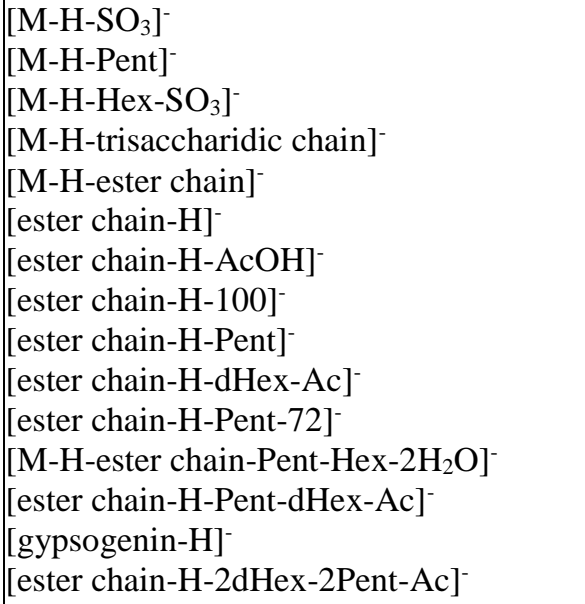 & 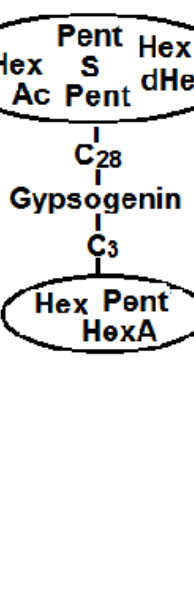 & 1779.6795 & $\begin{array}{c}\mathrm{C}_{77} \mathrm{H}_{120} \mathrm{O}_{44} \mathrm{~S} \\
1780.6873\end{array}$ \\
\hline $\begin{array}{l}19 \mathrm{~b} \\
19 \mathrm{c}\end{array}$ & $\begin{array}{l}1779.679 \\
1779.684\end{array}$ & & & $\begin{array}{l}10.87 \\
11.54\end{array}$ & $\begin{array}{l}\text { not } \\
\text { fragmented }\end{array}$ & & & & \\
\hline $20 a$ & 1809.693 & 4 & 3 & $11.68^{*}$ & $\begin{array}{r}1177.503 \\
869.228 \\
707.171^{3} \\
681.158 \\
607.118 \\
579.216 \\
527.162 \\
519.102 \\
503.104 \\
469.335 \\
241.002\end{array}$ & 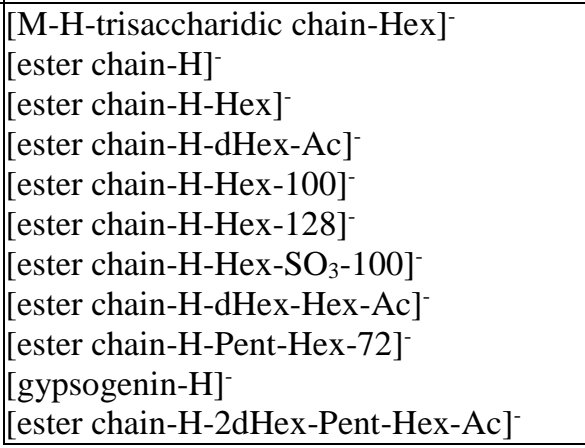 & 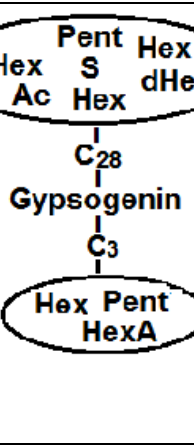 & 1809.6901 & $\begin{array}{c}\mathrm{C}_{78} \mathrm{H}_{122} \mathrm{O}_{45} \mathrm{~S} \\
1810.6979\end{array}$ \\
\hline
\end{tabular}




\begin{tabular}{|c|c|c|c|c|c|c|c|c|c|}
\hline $\begin{array}{l}20 b \\
20 c \\
20 d \\
\end{array}$ & $\begin{array}{l}1809.690 \\
1809.695 \\
1809.691 \\
\end{array}$ & & & $\begin{array}{l}11.60 \\
11.87 \\
12.36 \\
\end{array}$ & $\begin{array}{l}\text { not } \\
\text { fragmented }\end{array}$ & & & & \\
\hline $\begin{array}{l}21 \mathrm{a} \\
21 \mathrm{~b}\end{array}$ & $\begin{array}{r}1525.672 \\
1525.672\end{array}$ & 1 & 2 & $\begin{array}{l}13.22 * \\
12.68\end{array}$ & $\begin{array}{r}939.4614 \\
759.3981 \\
627.356 \\
583.364 \\
565.354 \\
469.332 \\
451.322 \\
439.321 \\
423.328 \\
405.316\end{array}$ & 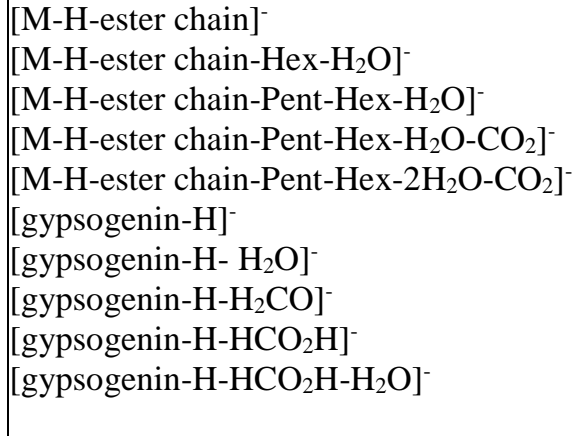 & $\begin{array}{c}\text { Hex } \\
\text { Hex dHe } \\
\text { Gypsogenin } \\
C_{28}^{\prime} \\
C_{3}^{C_{3}} \\
\text { Tex Pent } \\
\text { HexA }\end{array}$ & 1525.6699 & $\begin{array}{r}\mathrm{C}_{70} \mathrm{H}_{110} \mathrm{O}_{36} \\
1526.6777\end{array}$ \\
\hline
\end{tabular}

*main isobar

${ }^{1}$ Pen, pentose; Hex, hexose; HexA, hexosuronic acid; dHex, deoxyhexose; S, sulfate group; Ac, acetyl group; MeCin, methoxycinnamoyl group

${ }^{2}$ Fragmentation pattern was consistent with saponin reference $\mathbf{D}$ (Table 1, Fig. X)

${ }^{3}$ Fragmentation pattern was consistent with saponin references A-C and saponin 10a ((Table 1, Fig. Y) 